\title{
MÖHUK Kapsamında İddet Müddetinin Soybağının Reddi Ve Babalık Davalarına Etkileri
}

\author{
The Effect of the Post-Marital Waiting Period on Action For Denial of \\ Lineage and Paternity Suit Within the Context of the Turkish Pila
}

Hatice Selin Pürselim ${ }^{* * *}$ (DD

\section{öz}

İddet müddeti, çağlardan beri hukuk sistemlerini meşgul etmiştir. Bunun nedeni doğacak çocuğun yüksek menfaatini koruyabilmek ve toplumun çekirdeğini oluşturan aile kavramının zarar görmesini engellemektir. Evliliğin sona ermesinden sonra kadının hamile olup olmadığının bilinmeden yeniden evlenmesi halinde, doğacak çocuğun kime ait olduğu meselesi kocayı manevi ve maddi olarak etkilemektedir. Türk kanun koyucu, mülga Medeni Kanun düzenlemesinde ve yürürlükteki Türk Medeni Kanunu’nda (TMK) bu hususun üzerinde durmuş; kadının belirli bir süre beklemesi şartıyla yeniden evlenebileceğini düzenlemiştir. TMK md. 132 uyarınca, evlilik sona erdiğinde kadın evliliğin sona ermesinden başlayarak üçyüz gün geçmedikçe evlenemeyecektir ve bu süre her halükârda doğumla sona erecektir. İddet müddetinin kaldırılması davası açılarak kadının hamile olmadığı tespit edildiği takdirde, yeniden evlenmek için bu sürenin tamamlanması aranmaz. Yabancılık unsuru taşıyan evlenme söz konusu ise acaba iddet şartının dikkate alınması gerekecek midir? Türk vatandaşı kadın için bu soruya olumlu cevap verilmesi gerekirken yabancı ülke vatandaşı kadın için bu cevap kadının milli hukukuna göre tayin edilecektir. Zira evlenme ehliyet ve şartları Milletlerarası Özel Hukuk ve Usul Hukuku Hakkında Kanun (MÖHUK) md. 13 uyarınca tarafların milli hukukuna tabidir. Mevzuatımız uyarınca, yabancı ülke vatandaşı kadının milli hukukunda bekleme süresi öngörülmemişse, evlendirme memurluklarınca bu süre dikkate alınamayacaktır. Çalışmamızda, Türk vatandaşı kadının yabancı ülke vatandaşı erkekle evliliği ve yabancı ülke vatandaşı kadının Türk vatandaşı erkekle evliliği kapsamında iddet müddetine dair evlenme engeli incelenmiştir. Türk vatandaşı kadından aranan iddet müddeti şartı birden fazla vatandaşlığa sahip olması yönünden tartışılırken, yabancı kadından aranmayan bu şartın neticeleri üzerinde durulmaya çalışmıştır. Yabancı ülke vatandaşı kadının yabancı ülke vatandaşı biyolojik babadan hamile olarak iddet müddeti şartına tabi kalmadan Türk vatandaşı erkekle evlenmesi ihtimalinde, soybağının reddi davası ve babalık davası açılabilir. Çalışmamızda her iki dava için yetkili mahkeme ve uygulanacak hukuk tespit edilmeye çalışılmıştır. İki dava da kapsamları itibarıyla çok detaylı ve kapsamlı konuları içerdiklerinden, maddi hukuk meselelerine sadece MÖHUK çerçevesinde incelediğimiz noktalarda yer verilmeye çalışılmıştır.

Anahtar Kelimeler: Soybağının Reddi, Babalık Davası, Türklerin Kişi Hallerine İlişkin Davalar, Soybağına Uygulanacak Hukuk, Soybağının Reddine Uygulanacak Hukuk, Babalık Davasına Uygulanacak Hukuk

* Doç. Dr. Marmara Üniversitesi Hukuk Fakültesi, Milletlerarası Özel Hukuk Anabilim Dalı

** Makalenin hazırlanmasında manevi desteğini esirgemeyerek verimli bir ortamda çalışmamı sağlayan sevgili kardeşim Halide Tuğçe Pürselim Tansuk’a şükranlarımla...

Sorumlu Yazar/Correspondence Author: Hatice Selin Pürselim

E-posta/E-mail: hselinpurselim@marmara.edu.tr 


\section{ABSTRACT}

The concept of the waiting period has always been a talking point for legal systems for many centuries. The main reason of this concept is to protect the best interests of the child to be born and to prevent harm to the family, a concept that constitutes the core of society. In case the woman remarries after the end of marriage without knowing whether she is pregnant, the problem of determining the father of the child may arise and such a problem can both materially and morally affect the husband of the dissolved marriage. The Turkish legislator put an emphasis on this matter in both the promulgated Civil Code and the Turkish Civil Code (TCC), which is currently in effect, and stipulated that a woman can only remarry after waiting for a certain period. Pursuant to Article 132 of the TCC, a woman cannot remarry for three hundred days starting from the end of the previous marriage and in any case, this period will end with birth. In case an action is initiated for the removal of the waiting period, and it is proved in this action that the woman is not pregnant, then the completion of this period will not be deemed necessary to remarry. In the case of a marriage that involves a foreign element, will it be necessary to take into account the said waiting period? For a Turkish woman, the answer will be positive. If the woman holds the citizenship of a foreign country, the answer will be determined according to her national law. This is because the legal capacity to marry and the conditions thereof are governed by the respective national laws of the parties pursuant to Article 13 of the Act on Private International and Procedural Law. Pursuant to our law, if the national law of the foreign woman does not provide for a waiting period, this such period cannot be taken into account by marriage officers. In our study, we will be discussing the concept of the waiting period within the context of the marriage of a Turkish woman and a foreign man as well as that of a foreign woman and a Turkish man. We will also be discussing whether having multiple citizenships will have any impact on a Turkish woman and what consequences this will have on this condition. Moreover, we will be examining the consequence of this condition when it is not deemed necessary for foreign women. In the event that a foreign woman marries a Turkish man when she was pregnant from her previous marriage with a foreign man without having to wait for a certain period, it is possible to initiate an action for denial of lineage as well as a paternity suit. In our study, we will be trying to determine the competent court and the applicable law for both types of actions. As both these actions consist of highly detailed matters, we will be mentioning their substantive aspects only within the context of the points that will be raised in the study.

Keywords: Denial of Lineage, Paternity Suit, Actions Concerning the Personal Status of Turkish Citizens, Law Applicable to Lineage, Law Applicable to the Denial Of Lineage, Law Applicable to Paternity Suit

\section{TÜRK HUKUKUNDA GENEL OLARAK EVLENME ENGELLERi}

Evlenme ile ortaya çıkan hukuki durumu mümkün olduğu kadar ayakta tutma prensibinin tarihçesi, kilise ve İslam hukukuna kadar gitmektedir ${ }^{1}$. Ancak bu anlayış her ne olursa olsun evliliğin devam etmesi anlamına gelmemektedir; evliliğin devamı değer yargılarından yoksun olarak bireylere ve topluma fayda yerine zarar veriyorsa, bu evliliğin geçerli bir evlilik olarak sürdürülmesinde yarar görülemeyecektir ${ }^{2}$. Bu halde, evlenmenin kuruluşu, devamı ve sona ermesinde taraf iradesinin rolü önem arz etmektedir.

1 Öztan, Bilge, Batıl Evlenmelerde Eşlerin Durumu, Ankara Üniversitesi Hukuk Fakültesi Dergisi 26/1-2, 1969, s. 193.

2 Öztan, Batıl Evlenme, s. 194. 
Türk hukukunda, evlenme için öncelikle tarafların özgür iradeleriyle, içlerinden birinin oturduğu yer evlendirme memurluğuna birlikte başvurmaları gerekir (TMK md. 134). Başvuru aşamasında, tarafların evlenme engeli oluşturacak hal ve şartlarının bulunmaması aranmaktadır. TMK'nın ikinci kısmı, bahsedilen evlenme ehliyeti ve engellerini düzenlemiştir. Evlenme sözleşmesini kesin hükümsüz kılan evlenme engelleri, kesin evlenme engelleri olarak anılmaktadır. Eşlerden birinin evlenme sırasinda evli olmasi ${ }^{3}$ veya sürekli sebeple ayırt etme gücüne sahip olmaması veyahut evlenmeye engel olacak kadar akıl hastalığı bulunması ile hısımlık mutlak butlana neden olan evlenme engellerindendir ${ }^{4}$. Kanunumuz uyarınca, erkek veya kadın on yedi yaşını doldurmadıkça evlenemez. Ancak, hâkim olağanüstü durumlarda ve önemli bir sebeple onaltı yaşını doldurmuş, olan erkek veya kadının evlenmesine izin verebilir (TMK md. 129). Ayırt etme gücüne sahip olmayanlar, yasal temsilcisinin izni olmayan küçükler ve kisttllar evlenemez (TMK md. 125, 126). Yasal temsilci haklı bir sebep olmadan evlenmeye izin vermiyorsa, bu noktada hâkimin yasal temsilciyi dinledikten sonra başvuran küçük/kısıtlının evlenmesine izin verebilir. TMK'da evlenme engelleri başlığ altında kimlerin hangi nedenlerle evlenemeyeceği belirtilmiştir. Düzenlememiz uyarınca hısımlık bir evlenme engelidir. Üstsoy ile altsoy arasında; kardeşler arasında; amca, dayı, hala ve teyze ile yeğenleri arasında hısımlık sebebiyle evlenme engeli bulunmaktadır. Aynı şekilde, kayın hısımlığ meydana getirmiş olan evlilik sona ermiş olsa bile, eşlerden biri ile diğerinin üstsoyu veya altsoyu arasında evlenme engeli bulunmaktadır. Hısımlık sebebiyle evlenme engeli sayılan son hal ise, evlat edinen ile evlatlığın veya bunlardan biri ile diğerinin altsoyu ve eşi arasındaki evlenme engelidir (TMK md. 129). Böyle bir evlilik mümkün kılınmış ise, evlatlık ilişkisi korunacak fakat evlenme

3 Yargitay 2. HD., E. 2002/2458, K. 05.03.2002, “4721 sayll Medeni Kanun’un 147/son maddesi; evliyken yeniden evlenen bir kimsenin önceki evliliği mutlak butlan kararı verilmeden önce sona ermişse ve ikinci evlenmede diğer eş iyi niyetli ise bu evlenmenin butlanına karar verilemeyeceğini hükme bağlamıştır. Davalılardan F. ilk eși A.dan Köln Mahkemesinin 17.3.1999 tarihli kararı ile boşanmış, bu karar Bakırköy 5. Asliye Hukuk Mahkemesinin 18.10.2001 günlü kararı ile tenfizine karar vermiş ve bu karar 21.12.2001 de kesinleşmiştir. F.nin ilk evliliği bu kararla sona ermiştir. Davalılardan H.'nin ikinci evliliğin yapılmasında kötü niyetli olduğu da isbat edilmemiştir. Gerçekleşen bu durum karşısında davanın reddi gerekirken yazılı şekilde iptal kararı verilmesi usul ve yasaya aykırıdır”, (Erişim: 04.03.2021, www.legalbank.net).

4 Öztan, Batıl Evlenme, s. 210; Öztan, s. 585; Gayretli Aydın, Seda, Kadın ve Kanuni Bekle Süresi, TBB Dergisi 136/2018, s. 274 vd.. Umumi Hıfzısıhha Kanunu (RG.06.05.1930/1489) md. 123 uyarınca frengi, cüzzam gibi hastalıklara yakalanmış kişilerin evlenmesi yasaklanmıştır; bu düzenlemenin niteliği için bkz. Tanrıbilir, Feriha Bilge, Yabancıların Türk Yetkili Makamları Önünde Evlenmesi ve Kamu Düzenine Aykırılık Meselesi, Milletlerarası Özel Hukukta Güncel Konular Sempozyumu, (Ed. Tiryakioğlu, Bilgin/Aygün, Mesut/ Altıparmak, Kübra, Ankara 2016, s. 460 vd. Yargıtay 2. HD. E. 2010/4833, K. 13.07.2011, “Dava, Cumhuriyet Savcısı tarafından davanameyle açılan, davalı kocanın evlilik tarihi itibariyle evlenmeye engel olacak derecede akıl hastası olması sebebine dayalı (T.M.K. madde 145/3) evliliğin mutlak butlan sebebiyle iptali istemine ilişkindir. Dosya içerisindeki belgelerden, davalı kocanın akıl hastası olduğu gerekçesiyle kendisine Almanya'da vasi atandığı anlaşılmaktadır. Yabancı mahkemece verilmiş bulunan "vasi atanmasına" dair karar Türkiye’de geçerlilik kazanmadığından sonuç doğurmaz (H.G.K.nun 8.7.2009 tarihli 2009/2-280esas, 2009/326 karar sayılı kararı. Davalı kocanın, resmi sağlık kurulu raporuyla evliliğin yapıldığı tarihte akıl hastası olduğunun tespiti halinde davalıya vasi atanması konusunda vesayet makamına bildirimde bulunulması, vesayet makamı tarafindan atanacak olan vasiye davanın yöneltilmesi, gösterdiği takdirde delillerinin toplanması ve sonucu uyarınca karar verilmesi gerekirken, yazılı şekilde hüküm tesisi doğru görülmemiştir. Kamu adına mutlak butlan sebebine dayalı olarak evliliğin iptali isteminde bulunan Cumhuriyet Savcısının (TMK madde 146/1) duruşmalara katılımı sağlanmadan yargılamaya devamla yazılı şekilde karar verilmesi usul ve yasaya aykırıdır. Temyiz edilen hükmün yukarda 1. ve 2 . bentlerde gösterilen sebeplerle bozulmasına, bozma nedenine göre diğer temyiz itirazlarının şimdilik incelenmesine yer olmadığına, temyiz peşin harcının istenmesi halinde yatırana iadesine, işbu kararın tebliğinden itibaren 15 gün içinde karar düzeltme yolu açık olmak üzere, 13.07.2011 gününde oybirliğiyle karar verildi” (Erişim: 07.03.2021, www.legalbank.net). 
geçersiz kabul edilecektir ${ }^{5}$. Taraflardan biri daha önce evlenmiş ise, bu evliliğin sona erdiğinin ispat edilmesi gerekmektedir (TMK md. 130). İlk evlilik, ölüm veya boşanma gibi sebeplerden biriyle sona ermiş olabilir. Daha önce evlenmiş olan taraf, bu evliliğinin sona erdiğini kanıtlamak suretiyle yeniden evlenebilecektir. Eşlerden biri gaip ise ve gaip olan kişinin eşi başka bir kişiyle evlenmek istiyorsa, mahkeme ilk evlilikle ilgili olarak evliliğin feshine karar vermedikçe bu kişi ikinci evliliğini yapamayacaktır (TMK md. 131). Kanun koyucu gaibin eşine bir imkân sağlamıştır: Gaip olanın eşi, gaiplik başvurusuyla birlikte evliliğin feshini de talep edebilecektir. Ancak ayrıca bir dava açarak evliliğin feshini de isteyebilir. Şayet ayrı bir dava açılması suretiyle evliliğin feshi talep edilecekse, bu davanın davacını yerleşim yeri mahkemesinde açılması gerekmektedir (TMK md. 131). Akıl hastalığı bulunan bir kimsenin evlenmesi prensip olarak evlenme engeli olarak kabul edilmiştir. Bu kişilerin evlenmelerinde tıbbi bir sakınca olmadığının sağlık kurulu raporuyla açıklanması gerekmektedir. Resmi sağlık kurulu raporuyla kişinin evlenebilir olduğu anlaşılmadıkça, bu kimseler evlenmez (TMK md. 133). Akıl sağlığı konusunda, evlenme anındaki sağlık dikkate alınacaktır; evlenme anında evlenme engeli oluşturacak bir hal söz konusu ise, evlenme batıl kabul edilmektedir 6 . Çalışmamız için önem arz eden iddet müddetinden doğan evlenme engeli TMK md. 132'de düzenlenmiştir ve kanımızca tüm bu sayılan evlenme engellerinden farklıdır. Çünkü yukarıda bahsedilen evlenme engelleri her iki taraf için de geçerliyken, iddet müddeti sadece kadına yönelik bir düzenlemedir ${ }^{7}$. Kadının tekrar evlenebilmesi için aranan bu sürenin amacının soybağının tespitine dair olduğu bilinmektedir. Diğer bir tartışma, iddet müddeti düzenlemesinin İslam hukukunun TMK üzerindeki etkisi olup olmadığ yönünde olabilir. Aşağıda yapılan incelemeler ışığında bu düşünceye olumsuz yanıt vermek gerekecektir. Bu kapsamda belirtmek isteriz ki, çalışmamızda bilinçli olarak iddet müddeti kavramını tercih ettik. Zira uygulamada, Yargıtay kararlarında ve doktrinde kanuni bekleme süresi yerine sıklıkla iddet müddeti kavramının kullanıldı̆̆ı görülmektedir ${ }^{8}$.

\section{EVLENME ENGELI OLARAK IDDET MÜDDETi}

\section{A. Türk Medeni Kanunu Kapsamında}

Mülga 743 sayılı Türk Kanunu Medenisi md. 95 iddet müddetini düzenlemekteydi. Bu düzenleme uyarınca, kocasının vefatı veya boşanma sebebiyle dul kalan yahut evliliğinin butlanına hükmedilen kadın vefattan, boşanmadan veya butlan hükmünden itibaren üç yüz gün geçmedikçe tekrar evlenememekte; süre ancak doğurmakla sona ermekteydi. Kadının hamile kalması mümkün değilse

5 Uludağ, Sabiha Nur, Evlenmenin Hükümsüzlüğü Sebepleri, Çankaya Üniversitesi Sosyal Bilimler Enstitüsü Özel Hukuk Anabilim Dalı, yayımlanmamış yüksek lisans tezi, Aralık 2019, s. 72.

6 Yargitay 2. HD., E. 2009/5045, K.08.06.2010; (Erişim: 04.03.2021, www.legalbank.net)

7 TMK kadın erkek eşitliği konusunda başarılı bir kanun olmasına rağmen kadının soyadı ve iddet müddetine dair tartışmalı hükümler içermesi eleştirilmektedir; bkz. Gayretli Aydın, s. 263. Ayrıca bkz. Pürselim Arning, Türk, Alman ve İsviçre Milletlerarası Özel Hukuklarında Ad, - Ada, Ad Değiştirme Davasına, Kayıt Düzeltme Davasına Uygulanacak Hukuk ve Tanıma Usulü-, Ankara 2014, s. 72, s. 237 vd.

8 Akıntürk, Turgut/Ateş Karaman, Derya, Türk Medeni Hukuku Aile Hukuku, İstanbul 2013, s. 291. Gayretli Aydın, s. 265. İddet kelimesi, İslam hukukunda "saymak, sayılan şeyin miktarı, adet” anlamına gelmektedir ve evliliğin herhangi bir sebeple sona ermesi durumunda kadının yeni bir evlilik yapabilmek için beklemek zorunda olduğu süreyi ifade eder; https://islamansiklopedisi.org.tr/iddet (Erişim: 04.03.2021). 
veya boşanma ile ayrılmış olan karı ve koca tekrar birbirleriyle evlenmek istedikleri takdirde, hâkim bu müddeti kısaltabilirdi. Düzenleme yürürlükteki Medeni Kanun'da da benzer şekilde yer almaktadır. TMK md. 132 uyarınca düzenlenen iddet müddetine dair evlenme engeli şüphesiz ki kadınların hamilelik süreci esas alınarak düzenlenmiştir. Evlilik sona ermişse, kadın evliliğin sona ermesinden başlayarak üç yüz gün geçmedikçe evlenemez. Bu süre, kadının doğum yapmasıyla mahkeme kararına gerek olmaksızın - sona erecektir.

Çocuğun ölü doğması veyahut düşük yapılması halinde de doğum gerçekleşmiş kabul edilecektir9 Üç yüz günlük süre, bir hamileliğin tamamlanmasındaki azami süre olarak kabul edilmiş ve böylelikle kanun koyucu tarafından soybağının karışması engellenmeye çalışılmıştır ${ }^{10}$. Ancak kadının hamile olmama ihtimalinin de değerlendirilmesi gerekir. Kadının önceki evliliğinden hamile olmadığının anlaşılması veya evliliği sona eren eşlerin yeniden birbirleriyle evlenmek istemeleri halinde mahkeme süreyi kaldıracaktır (TMK md. 132). Mülga Kanun'da "kısaltılabilir" denilirken TMK md. 132'de "kaldıracaktır" kelimesinin kullanılması bilinçli bir tercihtir; zira kadının hamile olmadığının anlaşılması halinde veya eşlerin tekrar evlenmesi durumunda hâkimin takdir yetkisi yoktur ve süreyi kaldırması gerekmektedir ${ }^{11}$. TMK md. 154 uyarınca, iddet müddeti kesin evlenme engeli olmadığından, kadın bu süreyi beklemeden evlendiğinde evliliği geçersiz sayılmayacaktır. Ancak bu evlilik nasıl gerçekleşecektir? Zira uygulamada iddet müddetinin fonksiyonunun daha farklı olduğunu ve süre dolmamışsa evlendirme memurlarınca bu sürenin dikkate alındığını fark etmekteyiz. Dolayısıyla, iddet müddetinin dolmamasının uygulamada evlenme engeli olarak değerlendirildiğini görmekteyiz ${ }^{12}$. Zira evlendirme memuru, başvuruları Evlendirme Yönetmeliği md. 23 uyarınca incelemek zorundadır. Yönetmelik md. 23 uyarınca, dosyayı inceleyen evlendirme memuru, incelemesi sonucunda evlenme engellerinden herhangi birinin varllğını tespit ettiği takdirde, evlilik başvurusunu reddedecektir ve bu hususu gerekçeli ve yazılı olarak taraflara derhal duyuracaktır. Tespit edilen evlenme engelinin mevcut olmadığı belgelerle ispatlanmadığı sürece veyahut evlenme engeli, nüfus kütüklerindeki bir işlem eksikliği sebebiyle ortaya çıkmışsa, bu eksiklik tamamlanmadıkça evlenme gerçekleştirilemeyecektir. Tereddüdümüz, süre tamamlanmadığı için kesin olmayan evlenme engeli yaratan iddet müddeti hangi gerekçeyle evlendirme memurunca süre dolmuş gibi kabul edilebileceği noktasında doğmaktadır ${ }^{13}$.

Kadının iddet müddeti sona ermeden yeni bir evlilik yapacak olması ihtimalinde, evlenme engelinin aşılması için TMK md. 132/III uyarınca iddet müddetinin kaldırılması davası açılması gerekir. Hasımsız olarak açılan davanın amacı, hamileliğin oluşmadığının tespiti ve gerçekleşecek

9 Öztan, Bilge, Aile Hukuku, Ankara 2015, s. 154.

10 Helvacı, Serap/Erlüle, Fulya, Medeni Hukuk, İstanbul 2016, s. 156.

11 Gayretli Aydın, s. 276.

12 Aynı yöndeki eleștiri için bkz. Gayretli Aydın, s. 276.

13 Gayretli Aydın, s. 276. Yargıtay 11. Ceza Dairesi, E. 2017/14034, K.13.12.2017, “Temyiz dıșı sanık ...un katılan ... ile resmi olarak evli olduğu ancak boşanma davası devam ettiği, süreç içinde sanık ... ile gayrı resmi birliktelik yaşadığı, boşanmanın 25.01.2012'de kesinleştiği, 20.04.2012 tarihinde ... isminde bir çocuğun dünyaya geldiği, çocuğun babası ... olmasına rağmen iddet müddeti içinde doğan ...’n evlilik birlikteliği içinde doğmuş gibi nüfusa baba hanesi ... olarak kayıt edilmesinden ibaret eylemde; sanık ...'in, ... yeni boşandığı ve kanunun aradığı süreyi doldurmadığı için resmi nikah yapamadıklarını,.." (Erişim: 04.03.2021, www.legalbank.net) 
yeniden evlenme nedeniyle bir çocuk doğması halinde, bu çocuğun boşanılan eşin soybağına dair bir karışıklık yaratmamasıdır ${ }^{14}$. Ancak boşanılan eş ile tekrar evlenilmesi amacıyla da bu dava açılabilir ${ }^{15}$. İddet müddeti, evlilik boşanma ile sona ermişse boşanma kararının kesinleştiği tarihte başlayacaktır ve tespite ilişkin bu davada yetkili ve görevli mahkeme kadının yerleşim yerindeki Aile mahkemesidir ${ }^{16}$; bu mahkemenin olmadığı yerlerde dava Asliye hukuk mahkemesinde açılacaktır ${ }^{17}$. Uygulamada iddet müddeti davasının hastane tespiti süreci çağımıza uymayan bir yapıya sahiptir. Davanın açıldığ gidilmeden önce mahkemede kadının bileğine mühür vurulmaktadır. Mühür kadının bileğinden silinmeden hastaneye başvurularak tetkik yapılması gerekmektedir. Tetkik neticesinde hastane kapalı zarf içerisindeki sonucu kadına vermektedir; kadının bu zarfı açmadan mahkemeye teslim etmesi gerekmektedir. Zarfın içindeki neticeyi kadından önce mahkemenin açıp okuması ve kadına bunu bildirmesi usulü uygulanmaktadır. Uygulamadan edinilen bilgiye göre bu usulün sebebi, mahkemeye başvuru yapan kadınla hastaneye giden kadının aynı kişi olduğunun tespitinin sağlanmasıdır. Ülkemizde yeknesak olarak uygulanan bu usulün yazılı olduğu yasal düzenlemeyi tespit edemedik. Ancak teknoloji ve bilim bu kadar ilerlemişken, hukukun temel prensiplerinin ve bireyin kişisel haklarının korunması neredeyse 2020'li yılların hedefi haline gelmişken bir insanın kimlik tespiti için bileğine mühür vurularak hastaneye gönderilmesi usulünü eleştirmekte ve bu durumun Avrupa İnsan Hakları Sözleşmesi (AİHS) md. 8 kapsamında düzenlenen özel hayat saygı ilkesine aykırılık oluşturacağ 1 kanaatindeyiz.

\section{B. İslam Hukuku Kapsamında Iddet Müddeti}

İslam dininin aile yapısına ve ailenin sürdürülmesine dair birçok düzenlemesi vardır. İslam hukukunda evlenme ve boşanma kurumlarına dair detaylı hükümlerin olması, İslam’ın aileye bakış açısını yansıtmaktadır ${ }^{18}$. Hz. Peygamber'in Allah katında en sevilmeyen helal boşanmadır hadisi, bu durumu daha da iyi ifade etmektedir ${ }^{19}$. Buradan ailenin korunmasının gerektiği ve boşanmanın son çare olarak sunulduğu anlaşılmaktadır. Şiddetli geçimsizlik ve benzeri sebepler evliliğin devamını imkânsız kılıyorsa ve evliliği sona erdirmek zorunlu bir hal alıyorsa boşanma mübah kabul edilmektedir ${ }^{20}$.

14 Gençcan, Ömer Uğur, Aile Hukuku, İstanbul 2011, s. 303.

15 Helvacı, İlhan, Gerekçeli Karşılaştırmalı İçtihatlı Türk Medeni Kanunu Cilt II, Aile Hukuku, İstanbul 2013, s. 59.

16 Hasımsız davalar sulh mahkemesinde açlmaktadır; ancak 4787 sayılı (RG.18.01.2003/24997) Aile Mahkemelerinin Kuruluş, Görev ve Yargılama Usullerine Dair Kanun md. 4 uyarınca iddet müddetinin kaldırılması davası aile mahkemesinde açlacaktır.

17 Gayretli Aydın, s. 278, 279.

18 Cin, Halil, İslam ve Osmanlı Hukukunda Evlenme, Ankara 1974, s. 6 vd.; Dağcı, Şamil, İslam Aile Hukukunda Evlenme Engelleri I (Sürekli Evlenme Engelleri), Ankara Üniversitesi İlahiyat Fakültesi Dergisi, 39-I/1999, s. 176, Aydın, Mehmet Akif, Türk Hukuk Tarihi, İstanbul 2010, s. 264; Görgülü, Ülfet, İslam Aile Hukukunda Bid’̂́Talak Meselesi, İslam Hukuku Araştırmaları Dergisi, 30/2017, s. 337.

19 Görgülü, s. 338; Erdem, s. 72 ve orada dipnot 3’te anılan yazarlar.

20 Görgülü, s. 337 vd; Dağcl, Şamil, İslam Aile Hukukunda Evlenme Engelleri II (Geçici Evlenme Engelleri), Ankara Üniversitesi İlahiyat Fakültesi Dergisi, Cilt: XLI, 2000, s. 166 dipnot 111'de anılan eserler, "Ibnü'I-Hümam. III/22; Karfal eş - Şaşi, VII/ 19,20; İbn Abidin, II/427; Ömer Nasuhi Bilmen, "Müslümantıkla İftirak-1 Zevceyn ", Sebilürreşad 
İslam aile hukukunun değişime en az açık olan alanlardan bir tanesi olduğu, İslam hukukunun uygulandığı ülkelerde bu alanda yapılan değişikliklerin aile hukukunun özünden veya maddi aile hukukundan ziyade usule dair olduğu (boşanmada şahit aranması veyahut boşanmanın mahkeme yoluyla yapılması gibi) ifade edilmektedir ${ }^{21}$. Kaynağını Roma hukuku sistematiğginden alan Kıta Avrupası hukukunda kamu ve özel hukuk ayrımı yapılarak, aile hukuku medeni hukuk meseleleri içerisinde dahil edilmektedir; İslam hukuku ise dini karakteri gereği modern hukukun tasnif dışı tuttuğu ibadet ilişkisini fikıhın bir bölümü olarak ele almakta, kamu hukuku-özel hukuk ayrımı yerine dünyevi hükümleri de münakahat, muamelat ve ukubat şeklinde ayrı bir değerlendirmeye tabi tutmaktadır ${ }^{22}$. Evlenme, boşanma, miras, süt, soybağı, vasiyet, nafaka gibi meseleler ahvalu'ş-şahsiye kavramı altında yer almaktadır; ahvalu'ş-şahsiye kavramı ise, Kıta Avrupası hukukundaki personal status (statut personnel) kavramına karşlık gelmektedir ${ }^{23}$. İslam aile hukukunun etkisinde kalarak yirminci yüzyılda hazırlanmış kanunların iddet müddetine geniş yer verdikleri; 1917 tarihli Osmanlı Hukuk-i Aile Kararnamesi’nde iddet müddeti ile ilgili on bir maddenin yer aldığı; bunun haricinde 1951 tarihli Ürdün, 1959 tarihli Irak Kanunları ile Fas, Tunus, Suriye Kanunlarında da iddetin klasik İslam hukuku kapsamında tanzim edildiği doktrinde ifade edilmiştir ${ }^{24}$.

İddet müddeti, nikahın etkilerinin tamamen sona ermesi için belirlenmiş bir süre olup, böylelikle tarafların pişman olmaları halinde evliliğe geri dönmeleri; kadın hamile ise soybağının tespiti veya vefat söz konusu ise kocasını kaybeden kadının bu sayede yas tutabilmesi amaçlanmıştır ${ }^{25}$. İslam hukukunda iddet, evliliğin herhangi bir nedenle sona ermesi halinde (ölüm, boşanma veya fesih) nikah kaidelerinin tamamen ortadan kalkması ve kadının yeni bir evlilik yapabilmesi için beklemesi gereken süreyi tanımlamaktadır ${ }^{26}$. İddet müddeti, detaylı tasniflere tabi tutulmuştur. Doktrinde, boşanma veya vefat iddeti olarak ikiye ayrılabileceği gibi süreli veya süresiz iddetler olarak da nitelendirildiği görülmektedir; örneğin boşanmanın şekline göre (talaktaki boş ol beyanının kaç defa dendiğine göre) boşanma iddeti, hamile kadının iddeti, kocası kaybolmuş kadının iddeti ayrı ayrı incelenmiştir ${ }^{27}$. Hamilelerin iddet müddeti doğumla sona ermektedir ${ }^{28}$. İslam hukukunda iddetin tek amacı soybağı karışıklığının önlenmesi değildir; kadının eşinin ölümünden duyduğu üzüntü ve kederini yas tutarak geçirmesi vefat iddeti (örneğin kocasıyla ayrı yaşamak zorunda kalmış kadının eşinin hatırasına saygı olarak bu süreye uyması gerekmektedir) olarak tanımlanmaktadır ${ }^{29}$.

Mecmuası, Cilt: XXII, Sayı: 579, s.103; Ahmed İbrahim s. 76; Hallaf, s. 146,147; el-Hafif, s.14,15; Ahmed Muhammed Zeki, s. 147 vd., Seydișehri, s. 270; Mahmasani, Turasu'l Hulefa, s. 421, 450".

21 Dağcl, s. 191.

22 Dağcı, s. 175 ve dipnot 1'de anılan "Mecelle-i Ahkamı Adliyye Mazbatası; Hoca Emin Efendizade Ali Haydar Efendi, Düreru'I-Hükkam Şerhu Mecelleti'I-Ahkam, Matbaa-i Tevsii Tibliat, Istanbul 1330,1/3,15,16; Ziyaettin Fahri Findıkoğlu, Aile Hukukumuzun Tedvini Meselesi, Ebu'l-ula Mardin’e Armağan, Kenan Matbaası, İstanbul 1944, s. 689”.

23 Dağcl, s. 176.

24 Cin, s. 122.

25 Erdem, s. 92; Dağcl, Geçici Evlenme Engelleri, s. 172 vd.

26 Cin, s. 117; Erdem, Suat, İslam Hukukuna Göre İddet ve İddet Bekleyen Kadının Nikahı, Cumhuriyet Üniversitesi İlahiyat Fakültesi Dergisi, Cilt: XVII, Sayı: 2, 2013, s. 71, 76.

27 Erdem, s. 79.

28 Talak 65/4; Erdem, s. 76.

29 Cin, s. 120; Erdem, s. 78. 
İddet müddetinin dolmasını bekleyen kadına açık evlilik teklifinde ("seninle evleneceğim” şeklinde bir teklif) bulunmak yasaktır ${ }^{30}$. Örneğin rac’at karısını rac’i talakla boşamış kocanın yeni bir nikah yapmadan ve karısının rızasını almadan iddet müddeti içinde karısına geri dönmesi anlamına geldiğinden, rac'i talaktan dolayı iddet müddeti bekleyen kadına açık ve kapalı evlilik teklifi yapılamayacağ kabul edilmektedir $^{31}$. Vefat iddetinde ve bain talak (üç defa boş ol denilen ayırıcı talak, bu talaktan sonra tekrar evlilik yapılması gerekmektedir) ${ }^{32}$ iddetinde ise üstü kapalı evlilik teklifi ("seninle evlenmeyi arzuluyorum” şeklinde bir teklif) yapılabilmektedir ${ }^{33}$. Boşanmış kadının iddet müddeti üç ay olarak tanımlanmaktadır ${ }^{34}$. İddet müddeti beklenmeden yapılan evliliğin iptal edilmesi gerektiği, aksi halde haram olacağı belirtilmekte; iddet müddetinin dolması halinde tarafların yeniden evlenip evlenmeyecekleri ise tartışmalı kabul edilmektedir ${ }^{35}$. Kocanın ölümü halinde iddet müddeti dört ay on gün olarak belirtilmiştir; ancak evlenme hangi sebeple sona ererse ersin kadın hamile ise bu sürenin çocuk doğuncaya kadar devam edeceği ifade edilmektedir ${ }^{36}$. Evlilik dışı hamile kalan kadının evliliği ise iddet müddetine tabi tutulmamaktadır ${ }^{37}$. İddet müddetinin dolaylı olarak kocayı da etkilediği, örneğin dört eşinden birini boşamış erkeğin, iddet müddeti dolmadan beşinci kadınla evlenemeyeceği veyahut boşandığı kadının iddet müddeti sona ermedikçe onun kız kardeşi ile evlenemeyeceği ileri sürülmektedir ${ }^{38}$.

\section{Mukayeseli Hukuk Kapsamında Iddet Müddeti}

Roma hukukunda iddet müddeti eşlerden birinin ölümü nedeniyle kalan eşin beklemesi gereken süre olarak tanımlanabilir. Roma hukukunda yer alan bu düzenleme, aşağıda kısaca yer vereceğimiz mukayeseli hukuk kaidelerinde de yer bulmaktadır. Roma hukukunda eşi ölen kadınların yeniden evlenebilmesi dördüncü yüzyılın sonunda yeniden düzenlenmiştir ${ }^{39}$. Bu düzenleme uyarınca iddet müddeti bir yll olup, bu süreye uymayan kadın şeref ve haysiyet yoksunu kabul edilmekteydi ${ }^{40}$. İddet müddetine uymayan kadına mirastan pay hakkı verilmiyordu ${ }^{41}$.

Kita Avrupası́nda iddet müddetiyle ilgili olan - tespit ettiğimiz - düzenlemelerin yürürlükten kaldırıldığı ve bu hususta olumlu veya olumsuz doktrinsel bir tartışmaya yer verilmediğigörülmektedir. O nedenle, mülga Kanun düzenlemelerine kısaca yer vereceğiz. 1900 yllında yürürlükte olan Alman Medeni Kanunu ( $\$ 1309$ BGB 1311) evliliğin sona ermesinden (butlan, ölüm ve boşanma) itibaren

30 Erdem, s. 90.

31 Erdem, s. 84 ve 88; Cin, s. 121; Ansay, Sabri Şakir, Hukuk tarihinde İslam Hukuku, Ankara 1958, s. 208.

32 Cin, s. 115; Dağcl, Geçici Evlenme Engelleri, s. 171.

33 Erdem, s. 90; Cin, s. 122; Dağc1, Geçici Evlenme Engelleri, s. 173.

34 Bakara, 2/228 ve Erdem, s. 90; Cin, s. 120 vd.; Dağcl, Geçici Evlenme Engelleri, s. 176.

35 Erdem, s. 91.

36 Ansay, s. 14; Cin, s. 119; Dağcı, Geçici Evlenme Engelleri, s. 174 vd.

37 Cin, s. 120.

38 Dağc1, Geçici Evlenme Engelleri, s. 172; Cin, s. 122.

39 Saar, Stefan Chr., Ehe, Scheidung, Wiederheirat: zur Geschichte des Ehe - und des Ehescheidungsrecht im Frühmittelalter (6.-10. Jahrhundert), (Ed.; Holzhauer, Heinz/Roth, Andreas, Ius Vivens Band: 6, Münster 2002, s. 76.

40 Saar, s. 76.

41 Saar, s. 76. 
kadına yönelik on ay iddet müddeti öngörmekteydi; fakat bu süreye uymak zorunlu değildi ${ }^{42}$. Evliliğin sona ermesinden itibaren kadının on ay beklemesinin soybağını kurmakta kesin bir ispat vasıtası olmayacağı; zira dünyaya gelecek olan çocuğun evlilik içi olsa da başka bir erkekten olabileceği düşüncesiyle 1998 tarihli Evlenme Hukuku Kanunu (EheschlRG) ile iddet müddetine dair hüküm yürürlükten kaldırılmıştır ${ }^{43} .1811$ yılında yürürlükte olan Avusturya Medeni Kanunu hamile olmayan kadın için iddet müddetini altı ay olarak belirlemişti. Bu süre dolmadan yapılan bir evlilik geçerli olmakla beraber, yeni evlilikle kadın eski eşine mirasçı olamıyordu. 1945 yılında yürürlüğe giren yeni Kanun'da iddet müddetine yer verilmemiştir. Mülga İsviçre Medeni Kanunu md. 103’te evliliğin sona ermesinden itibaren kadının 300 gün beklemesi gerektiği düzenlenmişti. Bu düzenleme 01.01.2000 tarihinde yürürlükten kaldırılmıştır ${ }^{44}$. Mülga düzenlemede, soybağının tespiti için evliliğin batıl olmasından veya sona ermesinden itibaren kadınların iddet müddetini beklemesi gerektiği fakat boşanılan eşle tekrar evlenilmesi halinde hâkimin bu süreyi kısaltabileceği düzenlenmişti ${ }^{45}$. Mülga düzenleme uyarınca, süre, her halükârda doğumla sona ermekteydi.

İddet müddetine İslam hukuku ve Roma hukuku kaynaklarında erişilmesi, bu düzenlemenin sadece Kıta Avrupası ile sınırlı olduğu şeklinde anlaşılmamalıdır. Tayland'da kadınların 310 günlük bir iddet müddeti söz konusu iken, bu sürenin Japonyada - 2016 yılında tamamen kaldırılması yönündeki eleştirilere rağmen - 100 günle sınırlandırılmışı ır ${ }^{46}$. Hinduların boşanma sonrası iddet müddeti 300 gün, $\mathrm{ABD}$ eyaletlerinde ise çiftlerin karşllıklı olarak birkaç gün beklemeleri gerektiği düzenlenmiştir ${ }^{47}$.

\section{MILLETLERARASI ÖZEL HUKUKTA IDDET MÜDDETININ SOYBAĞINA YANSIMALARI}

Çalı̧̧mamızın sistematik bir şekilde ilerleyebilmesi için bu kısımda, Türk vatandaşı olan ve yabancı ülke vatandaşı olan kadınlar arasında bir ayrım yapılmıştır. İlk olarak Türk vatandaşı kadının yabancı ülke vatandaşı erkekle evliliği üzerinde kısaca durulacaktır. Türk vatandaşı kadınlar için TMK kapsamında iddet müddeti evlenme engeli sayılacağından, bu şart evlenmeden önce aranacaktır. Ancak Türk vatandaşı kadının birden fazla vatandaşlığa sahip olması MÖHUK md. 13’te yer alan evlenme ehliyet ve şartlarına dair bağlama noktasını etkileyeceğinden, bu noktada MÖHUK md. 4’ten doğan tartışmalara yer verilecektir. İkinci başlık altında, yabancı ülke vatandaşı kadının iddet müddetine tabi kalmadan evlenmesi sebebiyle ortaya çıkacak ihtilaflara ağırlık verilmiştir. Yabancı

42 Rauscher, Thomas, Familienrecht, München/Heidelberg 2008, s. 101, 102; Beitzke, Günther, Familienrecht: ein Studienbuch, München 1985, s. 54.

43 Rauscher, s. 121.

44 Kanun için bkz. https://www.vfst.de/apps/elbib/A153 ve ayrıca bkz. http://www.koeblergerhard.de/Fontes/ZGB1907. htm (Erişim: 04.03.2021).

45 Stehlin, Philipp, Das Personen - und Familienrecht des ZBG von 1912: Eine inhaltliche Untersuchung der Gesetzeskommentare des August Egger (1875-1954), Bern 2018, s. 116.

46 Paksoy Erbaydar, Nüket/Balseven Odabaşı, Aysun, Medeni Kanunun Bekleme Süresi (İddet Müddeti) İle İlgili 132. Maddesinin Kadın Hakları ve Modern Tıptaki Gelişmeler Işı̆̆ında Değerlendirilmesi, Fe Dergi 10/2108, s. 113-114’te anilan kaynaklar.

47 Paksoy Erbaydar/Balseven Odabaşı, s. 113-114'te anılan kaynaklar. 
ülke vatandaşı kadının iddet müddetine uymadan evlenmesi halinde açılması muhtemel davalar olan soybağının reddi davası ve babalık davası MÖHUK kapsamında değerlendirilecektir. İncelenen hususlara bir başlık altında yer verilmişse, tekrardan kaçınmak amacıyla diğer başlık altında bu hususlar değerlendirilmeyecektir.

\section{A. Türk Vatandaşı Kadının Yabancı Ülke Vatandaşı Erkekle Evliliği}

\section{Genel Olarak}

Yabancılık unsuru taşıyan evliliklerde, MÖHUK md. 1 uyarınca uygulanacak hukukun belirlenmesi gerekmektedir. Evliliğin gerçekleşebilmesi için aranan şartlara uygulanacak hukuku belirlemede sunulan görüşler, evlenmeyi yapan kişiler ve evlenme işlemi açısından iki farklı esasa dayanmaktadır ${ }^{48}$. Evlenmenin yapılmasındaki maddi şartlar ise evlenme iradesi, ehliyet ve evlenme engelleri olarak üç başlık altında değerlendirilmektedir ${ }^{49}$.

MÖHUK md. 13 uyarınca, evlenme ehliyeti ve şartları, taraflardan her birinin evlenme anındaki milli hukukuna tabidir. MÖHUK md. 2/III uyarınca evlenme ehliyet ve şartları belirlenirken atfın dikkate alınması gerekmektedir. Atıf, hem evlenme ehliyeti hem de evlenme şartları açısından uygulama alanı bulacaktır ${ }^{50}$. Yetkili hukuk olan milli hukuk, örneğin yerleşim yeri hukukuna gönderme yapıyorsa, yerleşim yeri hukukunun maddi hükümleri dikkate alınacaktır ${ }^{51}$. Türk vatandaşı kadın ve yabancı ülke vatandaşı erkeğin evlenme ehliyet ve şartlarına uygulanacak hukuk MÖHUK md. 13 uyarınca evlenme anı dikkate alınarak belirlenecektir ${ }^{52}$. Yabancı ülke vatandaşı erkek için evlenme ehliyeti ve

48 Sayman, Yücel, Türk Devletler Hususi Hukukunda Evlenmenin Kuruluşu, İstanbul Üniversitesi Hukuk Fakültesi Yayınları, İstanbul 1982, s. 9.

49 Tekinalp, Gülören, Milletlerarası Özel Hukuk Bağlama ve Usul Hukuku Kuralları, İstanbul 2020, s. 133.

50 Çelikel, Aysel/Bahadır, Erdem, Milletlerarası Özel Hukuk, İstanbul 2020, s. 233.

51 Güngör, Gülin, Türk Milletlerarası Özel Hukuku, Ankara 2021, s. 136.

52 Yargitay 2. HD. E. 2007/6488, K. 17.03.2008, “Tarafların Almanya'da Alman Hukukuna uygun olarak resmi memur önünde evlendikleri, bu evliliğin Alman Nüfusunda kayıtlı olduğu ancak; davacı Ahmet'in Alman vatandaşı karısının soyadını alması nedeniyle Türkiye'deki Ahmet'in nüfusuna kaydının yapılmadığı hususlarında bir uyuşmazlık bulunmamaktadır. Davacı, Ahmet, Alman eşinden Alman Mahkemesinin kararıyla boşandığını belirterek bu kararın tanınmasını istemiş, yerel mahkeme; "Tarafların evliliğinin Türk yasaları çerçevesinde geçerli olmadığından nüfusa kaydedilmediğini, bu nedenle de tanıma isteğinde bulunulmayacağı” gerekçesiyle isteği reddetmiş karar davacı tarafından temyiz olunmuştur. Davacının, daha sonra evlendiği Türk vatandaşı karısını Almanya'ya götürmek istediği ancak Almanya’da verilen boşanma kararı tanınmadığından bunun mümkün olamaması nedeniyle temyize konu davayı açtı̆̆ı anlaşıldığından; davanın görülmesinde hukuki yararının bulunduğu hususu sabittir. Evlenme tarafların evlendirme memuru huzurunda evlenme iradelerini açılamalarıly oluşur. (TMK. m. 142). Evlenme iradesinin olumlu şekilde evlendirme memuru önünde açıllanmasıyla oluşan evlenme aktinin; nüfus siciline kaydedilmemiş olması, akti geçersiz kılmaz. (YİBK, 14.6.1965 t, 3/3). Evlenme ehliyet ve şartları, taraflardan her birinin evlenme anındaki milli hukukuna tabidir. Evliliğin şekline yapıldığı ülke hukuku uygulanır. (5718 s. MÖHUK. m. 13) Yurt dışında yabancı yetkili makamlar önünde Türk Vatandaşlarının yaptığı evlenmeler 4721 sayılı Türk Medeni Kanunu hükümlerine uygun olmak ve butlanla batıl olmayı gerektiren bir sebep bulunmamak kaydıyla geçerlidir. Evlenmekle Türk vatandaşlığını kazanan kadın, kocasının hanesine tescil edilir. (5490 sayılı Nüfus Hizmetleri Kanunu m. 24, 25) Davacının Almanya'da Alman vatandaşıyla yaptığı evlilik akdi şekil yönünden 5718 sayılı Milletlerarası Özel Hukuk Usulleri Kanununun madde 13/2'ye uygun olup ” evlenme akdi” gerçekleşmiştir. Davacının Alman eşinin soyadını alması nedeniyle bu şekilde kaydının Türk nüfusuna yapılmaması (TMK: m. 187) bu evliliğin geçersiz kılmaz ve yok sayılmasını gerektirmez. O halde isteğin 5718 sayılı Milletlerarası Özel hukuk Usulleri Kanununun maddi 53, 54, 58. hükümleri çerçevesinde incelenip bir 
şartları kendi milli uyarınca; Türk vatandaşı kadın için Türk hukuku uyarınca belirlenecektir. Özetle, taraflardan biri için aranan koşullar diğerinin de milli hukukunda aynı şekilde yer almadıkça karşı taraftan aranmayacaktır ${ }^{53}$. Bir görüş, evlenme engellerini iki taraflı ve tek taraflı evlenme engelleri şeklinde ayırmaktadır; tek taraflı evlenme engelleri hangi tarafın milli hukukunda düzenlenmiş ise onun evlenmesini engellerken, iki taraflı evlenme engelleri her iki tarafı da etkilemektedir ${ }^{54}$. Savunulan görüş, evlenme engellerinin iki taraflı ve tek taraflı evlenme engeli olmasından hareketle, bu engellerin sadece bir tarafın milli hukukunda yer alsa bile her iki taraf için de aranması gerektiğini, aksi takdirde evlenmenin geçersiz olacağını ifade etmektedir ${ }^{55}$. Bu görüş uyarınca örneğin, evlenme yaşı tek taraflı evlenme engeli olarak nitelendirilirken, birden fazla evliliğin söz konusu olma hali - iki tarafı da etkilediğinden - iki taraflı evlenme engeli olarak değerlendirilmektedir ${ }^{56}$. MÖHUK md. 13/I'de yer alan evlenme ehliyet ve şartlarından yakın hısımlığın, mevcut evliliğin, akıl hastalığının, bulaşıcı hastalığın ve eşlerin aynı cinsten olmasının iki taraflı evlenme engeli olarak kabul edilmesi gerektiğini ifade eden görüşe ${ }^{57}$ katılmamaktayız. Kanaatimizce, hem maddenin lafzından ve ruhundan bu sonuca ulaşamamaktayız hem de bu gibi hususlar Türk kamu düzenine açık aykırılık yaratacağından MÖHUK md. 5 uyarınca engellenebilecektir ${ }^{58}$. Bu noktada, evlenmek isteyen kişiden, müstakbel eşinin milli hukukunda bulunan evlenme koşul ve engellerine uymasını aramak beklenmeyeceği düşüncesinden hareket etmekteyiz ${ }^{59}$. Evlenecek kişi zaten evli ise, akıl hastalığı veya bulaşıcı bir hastalığ varsa, taraflar arasında yakın hısımlık söz konusu ise veyahut taraflar aynı cinsten ise iki taraflı evlenme engeli olarak nitelendirilen bu hallerde zaten MÖHUK md. 5 kapsamında yabancı hukukun belirli bir olaya uygulanan hükmünün Türk kamu düzenine açık aykırı olması halinde uygulanacaktır ${ }^{60}$.

\section{Evlenme Ehliyet ve Şartları Yönünden Vatandaşlık Bağlama Noktasına Dair Düşünceler}

\section{a. MÖHUK md. 4/I-b’nin Uygulanmasına Dair Düşünceler}

Vatandaşlık günümüze dek aile hukuku, kişiler hukuku ve miras hukuku alanlarında gücünü hissettiren bir bağlama noktasıdır ${ }^{61}$. Tarafların milli hukuku, evlenme ehliyet ve şartlarına

karar verilmesi gerekirken yazılı olduğu şekilde reddine hükmedilmesi usul ve yasaya aykırıdır. Sonuç: Temyiz olunan karanın açıllanan sebeple bozulmasına, bozma sebebine göre diğer yönlerin incelenmesine yer olmadığına, temyiz peşin harcının yatırana geri verilmesine, işbu kararın tebliğinden itibaren 15 gün içinde karar düzeltme yolu açık olmak üzere oyçokluğuyla karar verildi, (Erişim: 07.03.2021, www.legalbank.net).

53 Şanl, Cemal/Esen, Emre/Ataman Figanmeșe, İnci, Milletlerarası Özel Hukuk, İstanbul 2021, s. 149 vd.; Aybay, Rona/ Dardağan, Esra, Uluslararası Düzeyde Yasaların Çatışması, İstanbul 2008, s. 200.

54 Tekinalp, s. 133.

55 Tekinalp, s. 133; Nomer, Ergin, Devletler Hususi Hukuku, İstanbul 2017, s. 239-245; Çelikel/Erdem, s. 233 vd., Akıncı, Ziya/Gökyayla Demir, Cemile, Milletlerarası Aile Hukuku, İstanbul 2010, s. 18 vd.

56 Tekinalp, s. 133; Nomer, s. 245.

57 Tekinalp, s. 133; Çelikel/Erdem, s. 234; Nomer, s. 239; Akıncı/Gökyayla Demir, Milletlerarası Aile Hukuku, İstanbul 2010, s. 19.

58 Şanlı/Esen/Ataman Figanmeşe, s. 150 vd; Doğan, Vahit, Milletlerarası Özel Hukuk, Ankara 2020, s. 322; Aybay/ Dardağan, s. 201; Can, Hacı/Toker, Ali Gümrah, Milletlerarası Özel Hukuk, Ankara 2016, s. 196.

59 Şanlı/Esen/Ataman Figanmeşe, s. 150-151.

60 Şanl1/Esen/Ataman Figanmeșe, s. 150-151.

61 Basedow, Jürgen, Das Staatsangehörigkeitsprinzip in der Europäischen Union, IPRax 2011, s. 109. 
uygulanacak hukukun tespitinde önem arz etmektedir. Yeniden evlenecek olan Türk vatandaşı kadının Türk hukuku uyarınca evlenme ehliyet ve şartlarını taşıması gerekmektedir. İddet müddetine riayet de bunlardan biridir. İddet müddetinin kaldırılması davasıyla kadının hamile olmadığı tespit edilmiş olacağından, bu evliliklerde soybağının tespiti yönünden bir ihtilaf yaşanmayabilir. Ancak Türk vatandaşı kadının birden fazla vatandaşlığı olabilir. Bu halde, MÖHUK md. 4/I-b uyarınca birden fazla devlet vatandaşlığına sahip olanlar hakkında, bunların aynı zamanda Türk vatandaşı olmaları halinde Türk hukukunun uygulanması gerektiğini, "Kanun'da aksi öngörülmedikçe" ifadesinin kişinin Türk vatandaşlı̆̆ını etkilememesi gerektiğini düşünmekteyiz ${ }^{62}$. Bu aşamada, bir kişinin birden fazla vatandaşlı̆̆ olup aynı zamanda Türk vatandaşı olması halinde en sıkı ilişkili hukukun uygulanıp uygulanmayacağı tartışmasına kısaca yer vermek gerekir. Çünkü bu ihtimalde, Türk vatandaşı kadın sıkı ilişkili hukuk sayesinde yabancı hukukun tesiri altında kalacak; iddet müddeti engelinden muaf olarak evlenebilecektir. Sıkı ilişkili hukukun uygulanmasına dair bir görüş, kişinin vatandaşlığını taşıdığı ülkelerden hangisi ile daha sıkı bağı varsa, o ülke hukukunun esas alınması gerektiğini savunmaktadır ${ }^{63}$. Bu görüş uyarınca, kişinin şahsi statüsü hakkında yetkili hukukun tespitini gerektiren vakıanın, vatandaşı olduğu ülkelerden birinin resmi merci huzurunda gerçekleşmiş olması doğrudan bu ülkenin hukukunun uygulanması sonucunu doğurmamalıdır ${ }^{64}$. Türk vatandaşının birden çok vatandaşlığı varsa ve de örneğin sosyal ve iş hayatını idame ettirdiği ülkenin vatandaşlı̆̆ına, Türk vatandaşlığına nazaran daha sıkı bir şekilde bağlıysa, buna rağmen bu kişinin Türk vatandaşlığının esas alınmaması düşüncesine katılmamaktayız ${ }^{65}$ ve bu düşüncemizi şu şekilde gerekçelendirmekteyiz: Türk vatandaşının örneğin evlenme sırasında sıkı ilişki nedeniyle $\mathrm{X}$ ülkesi vatandaşlı̆̆ kapsamında evlenme ehliyet ve şartlarına bakılırken, aynı kişi Türkiyéde taşınmaz almak istediğinde $\mathrm{X}$ ülkesi vatandaşlığını mı kullanacaktır yoksa mevzuatın kendisine sağladığı haklardan yararlanmak amacıyla Türk vatandaşlığının esas alınmasını $\mathrm{m} ı$ isteyecektir? Bu düşünceden hareketle, MÖHUK kapsamında "tarafların müşterek milli hukuklarının" arandığı maddelerde de kişinin vatandaşlıklarından bir tanesi Türk vatandaşlı̆̆ ise, bu kişinin sadece Türk vatandaşlığının esas alınması gerektiği kanısındayız; zira bu kişi X ülkesi hukukuna göre $\mathrm{X}$ ülkesi vatandaşıyla nişanlandığında nişanlanmanın hüküm ve sonuçlarına müşterek milli hukukları olan X hukuku uygulanırken, aynı kişi çalışma hayatına atılmak istediğinde Türk vatandaşlığını kullanarak Türk hukuku uyarınca Türklere mahsus mesleklerde çalışabilecektir. Hukuki ihtilafa göre, kişinin

62 Nomer, s. 115; Şanlı/Esen/Ataman Figanmeşe, s. 37; Çelikel/Erdem, s. 67; Nomer, Ergin, Türk Devletler Özel Hukukunda Çifte Vatandaşlık, MHB, 14/I-II, 1994, s. 35 vd; Martiny, Dieter, Probleme der Doppelstaatsangehörigkeit im deutschen Internationalen Privatrecht, JZ, 23/1993, s. 1145 vd. Ayrıca bkz. Berki, Şakir, Evlenmenin Asli Şartlarından Doğan Kanun İhtilafları ve Türk Hukukundaki Tatbikatı, Ankara Üniversitesi Hukuk Fakültesi Dergisi, Cilt: 8, Sayı: 1-2, 1951, s. 613. "Tarafların Türk vatandaşlığı dahil birden çok müsşerek vatandaşıı̆ı, bir başka ifadeyle birden çok müşterek mili hukuku varsa veya taraflar Türk vatandaşı olmayıp birden çok müşterek yabancı vatandaşlı̆̆a sahip ise sorunun halli md. 4/1-b ve c işletilmeden mümkün görünmemektedir. Bu itibarla fikrimizce bu iki bend tekil ve paylaştırmalı bağlama içeren bağlama kurallarının yanı sıra müşterek bağlama kabul etmiş bağlama kurallarının sırasında da işlevseldir”, Güngör, s. 54 .

63 Ayrıntılı bilgi için bkz. Doğan, s. 213.

64 Doğan, s. 213. Yazar, "birden fazla ülkeye vatandaşlık bağı ile bağlı olan kişi, aynı zamanda hakimin ülkesinin de vatandaşlğ̆ına sahip ise hakimin ülkesinin vatandaşlı̆̆ esas alınacak, şahsi statü hakimin hukukuna tabi olacaktır" şeklindeki görüşün pozitif düzenlemelerde de kabul edilen görüş olduğunu ve bu görüşün Türk hukukunda da kabul edildiğini ayrıca belirtmektedir; ayrıntılı bilgi için bkz., s. $213 \mathrm{vd.}$

65 Pürselim Arning, Hatice Selin, Temel Kavramlar Işı̆̆ı̆ında Mülteci Hukukunun Gelişimi, (Ed. Öner, Aslı Şirin/Ihlamur Öner, Suna Gülfer) Uluslararası İlişkilerde Göç, İstanbul 2018, s. 222. 
farklı vatandaşlıklarını kullanarak kendi menfaatine göre çözüme ulaşma anlayışının MÖHUK’un amacına ve diğer kanunlarla arasındaki ahenge zarar vereceğini düşünmekteyiz.

\section{b. MÖHUK md. 4/I-c'nin ve md. 4/I-a'nın Uygulanmasına Dair Düşünceler}

Yabancı devlet vatandaşı evlenecek olan erkeğin birden fazla vatandaşlığı olması halinde MÖHUK md. 4/I-c uygulanacaktır ${ }^{66}$. Böyle bir durumda, birden fazla devlet vatandaşlı̆̆ına sahip olan, ancak Türk vatandaşlığı olmayanlar hakkında, daha sıkı ilişki halinde bulundukları devlet hukukuna bakılması gerekmektedir. Sıkı ilişki halinde bulunulan devlet hukuku tanımının hukuk sosyolojisi alanına girdiği; sıkı ilişkili vatandaşlığın tespiti için etkili ${ }^{67}$ ve gerçek bağa ${ }^{68}$ bakılması gerektiği, vatandaşlık hukuku kapsamında değerlendirilmemesi gerektiği; yaşanılan yer, mutad mesken, iş yeri, okul ve sosyal çevre, kişinin konuştuğu lisan gibi faktörlerin beraber dikkate alınabileceği ileri sürülmektedir ${ }^{69}$. Ayrıca, son kazanılan vatandaşlı̆ı̆n sıkı ilişkide önemli olduğunu üzerinde durmakta, örneğin çocuk evlat edinme yoluyla vatandaşlık kazanmışsa ve bundan sonraki yıllarda kendi iradesiyle başka bir vatandaşılık daha edinmişse bu aşamada sıkı ilişki tespiti için geniş bir perspektifle karar verilmesinin önemli olduğu ifade edilmektedir ${ }^{70}$. Kanımızca kişinin kazandığ 1 vatandaşlığa bağlı olarak adını değiştirmesi sıkı ilişkinin tespitinde önemli bir ölçüttür ${ }^{71}$.

Yabancı devlet vatandaşı olarak farz ettiğimiz eş, hiçbir ülkeye vatandaşlık bağıyla bağlı olmayabilir veyahut mülteci olabilir ${ }^{72}$. Son zamanlarda dünyada yaşanan olaylar nedeniyle mülteci kavramının genişletilmeye çalışıldığ görülmektedir. Mülteci tanımının 1951 tarihli Birleşmiş Milletler Mültecilerin Hukuki Statüsüne İlişkin Cenevre Sözleşmesi ${ }^{73}$ ve 1967 tarihli New York Protokolü kapsamında belirlenmesi gerektiğini; mevcut ihtilaflara hızlı çözüm bulmak adına benzer durumdaki kişilerin ihtilaflarını Sözleşme kapsamında çözmeye çalışmak yerine, bu kişiler için

66 Milletlerarası sözleşmede bağlama noktası olarak vatandaşlıktan hareket edilmesi halinde uygulanacak hukukun tespitine dair tartışmalar için bkz. Ataman Figanmeşe, İnci, Çifte Vatandaşlık Halinde MÖHUK'un 4. maddesinin b ve c Bendlerinin Uygulama Alanı, MHB, Aysel Çelikel’e Armağan, Sayı: 1-2, 1999/2000, s. 102 vd.

67 Etkin (efektif) vatandaşlık kavramını ilk olarak Brocher (1880) ve Neumann (1896) kullanmıştır; detaylı bilgi için bkz. Mansel, Heinz-Peter, Personalstatut, Staatsangehörigkeit und Effektivität, München 1988, Rn. 107. Efektif vatandaşlık kavramı (Alman MÖHK md. 5) Türk doktrininde etkili vatandaşlık ve gerçek bağ oluşturan vatandaşlık şeklinde değerlendirilmektedir, bkz. Nomer, (Çifte Vatandaşlık), s. 58; Çelikel/Erdem, s. 68. Güngör, s. 53.

68 Gerçek bağ kavramına dair açıklamalar için bkz. Mansel, Rn. 174 vd.; Schulze, Reiner, Art. 5 EGBGB, in: Nomos Kommentar BGB I, Baden Baden 2012, Rn. 22; Hailbronner, Kay, Staatsangehörigkeit und IPR, in: Hailbronner, Kay/ Maaßen, Hans-Georg/Hecker, Jan/Kau, Marcel, Staatsangehörigkeitsrecht, München 2017, Rn. 5; Angelika Fuchs, Neues Staatsangehörigkeitsgesetz und Internationales Privatrecht, NJW 2000, s. 491.

69 Schulze, Rn. 22; Rentsch, Betina, Die Zukunft des Personalstatuts im gewöhnlichen Aufenthalt, ZEuP, 2015, s.288; Martiny, s.1145; Fuchs, s. 491, 492.

70 Lorenz, Stephan, EGBGB Art. 5, in: Hau, Wolfgang/Poseck, Roman, BeckOK BGB, 2021, Rn. 8, 9.

71 Ayrıca bkz. Pürselim Arning, s. 315.

72 İklim mültecisi, ülkeleri içinde yerinden edilmiş kişiler ve deniz yoluyla gelen sı̆̆ınmacı kavramlarının mülteci kavramıyla karşılaştırılması açısından bkz. Pürselim, Hatice Selin, Mültecilerin Hukuki Statüsüne İlişkin Cenevre Sözleşmesi’ne Yönelik İki Tartışma: Sözleşme’nin Kapsadığı Kişiler ve Geri Göndermeme İlkesinin Bağlayıcılığı, Prof. Dr. Necla Giritlioğlu'na Armağan, (Ed. Erman, Hasan/ Öğüz, Tufan/ Şıpka, Şükran/İnal, Emrehan/ Baysal, Başak), İstanbul 2020, s. 519, 523, 525 .

RG. 05.09.1961/10898. 
ivedilikle özel durumlarına dair ayrı uluslararası çalışmalar yapılması gerektiği düşüncesindeyiz ${ }^{74}$. $\mathrm{Bu}$ nedenle, ilgilinin sığınmacı olması halinde, mülteci olarak kabul edilip edilmeyeceği henüz belirli olmadığından ve mültecilik talebi başvuru aşamasında olduğundan, vatansız kavramı altında MÖHUK md. 4 uyarınca uygulanacak hukuk tespit edilebilir ${ }^{75}$. Doktrinde, MÖHUK md. 4/I-a hükmünde yer alan mülteci kavramının kapsamına 6458 sayılı Yabancılar ve Uluslararası Koruma Kanunu'nda öngörülen koruma statülerine dahil bütün yabancıların gireceğine dair görüş savunulmaktadır ${ }^{76}$. Bu görüş uyarınca, 1961 Cenevre Sözleşmesi’ne tabi olan mülteciler bakımından konuya dair özel bir düzenleme getirildiği; MÖHUK md. 4/I-a hükmündeki mülteci kavramının geniş yorumlanması gerektiği ifade edilmektedir ${ }^{77}$.

MÖHUK md. 4/I-a'daki mülteci kavramı ise, temel düzenleme olan 1951 tarihli Cenevre Sözleşmesi’ndeki tanım esas alarak değerlendirilmelidir. Yabancının vatansız veya mülteci olması halinde MÖHUK md. 4/I-a uyarınca Türkiye’de kaldıkları süre içerisinde yaptıkları veya muhatap oldukları işlemlerde yerleşim yeri, bu yer bulunmadığı hallerde mutad mesken, o da yok ise dava tarihinde bulunduğu ülke hukuku olarak Türk hukukunun esas alınması; Türkiye’ye gelmeden önce gerçekleştirdikleri işlemlerde ise MÖHUK md. 4/I-a yerine ihtilafın milli hukuklarına göre çözülmesi gerekecektir ${ }^{78}$.

Anayasa md. 90/V ve MÖHUK md. 1/II uyarınca milletlerarası sözleşmelerin uygulama bulduğu alanlarda öncelik sözleşmelerin olacağından, bu hususla ilgili düzenlemelere yer verilmesi gerekir. MÖHUK md. 4/I-a bendi, milletlerarası sözleşmeler kapsamında bulunmayan vatansız ve mültecileri esas almaktadır. Sözleşme kapsamına giren vatansız ve mülteciler için, akid olduğumuz iki milletlerarası sözleşmeye bakılması gerekmektedir. Vatansız Kişilerin Statüsüne Dair Anlaşma md. $12 / \mathrm{I}^{79}$ uyarınca evlenme ehliyeti yerleşim yeri hukukuna, bulunmaması halinde kişinin oturduğu devletin hukukuna tabi olacaktır ${ }^{80}$. 1951 tarihli Cenevre Sözleşmesi de benzer bir düzenleme içermektedir. Sözleşme md. 12/I uyarınca ${ }^{81}$, evlenme ehliyetine ilgilinin yerleşim yeri hukuku,

74 Pürselim, s. 536 vd.

75 Alman MÖHK'taki benzer düzenlemeye dair aynı yöndeki düșünce için bkz. Hailbronner, Staatsangehörigkeit und IPR, Rn. 10. Yargitay 2. HD. E. 2009/19552 K. 2010/2037, 08.02.2010 tarihli kararında "Tarafların ikisinin de Afgan uyruklu oldukları, Birleşmiş Milletler Mülteciler Yüksek Komiserliğince verilen "mülteci" belgesine istinaden 3.7.2007 tarihinden beri Türkiyede "sığınmacı" olarak bulundukları anlaşılmaktadır. Tarafların "evli" olduklarına ilişkin dosyada bir belge bulunmamaktadır”, denilmektedir. Yargıtay kararında bu kișinin mülteci olarak kabul edildiği görülmektedir. Ancak kararda ilgili kişiye Yüksek Komiserlik tarafından mülteci belgesi verildiği ayrıca belirtilmiștir. (Erişim: www. legalbank.net, 04.03.2021).

76 Şanlı/Esen/Ataman Figanmeşe, Milletlerarası Özel Hukuk, İstanbul 2021, s. 35, dn. 63.

77 Şanlı/Esen/Ataman Figanmeșe, s. 35, dn. 63; Güngör, s. 53; Çelikel/Erdem, s. 69; Tekinalp, s. 65-66, dn. 25.

78 Şanlı/Esen/Ataman Figanmeşe, s. 37; 07.07.2006 tarihli MÖHUK Tasarısı Madde Gerekçeleri, https://www2.tbmm.gov. $\operatorname{tr}$ (Erişim: 04.03.2021).

79 Kişisel Statü başlıklı madde şu şekildedir: "Vatansız bir kişinin kişisel statüsü daimi ikametgahının ait olduğu ülkenin kanununa, ikametgâhı yoksa oturduğu ülkenin kanununa göre düzenlenir (12/I). Vatansız bir kişi tarafından daha önce elde edilen ve kişisel statüye ilişkin olan haklara, özellikle evliliğe bağlı haklara, her Sözleşmeci Devlet tarafından, eğer bu gerekliyse, söz konusu devletin yasalarının gösterdiği koşulları yerine getirmek kaydıyla, saygı gösterilir; ancak, söz konusu hakkın, kişi vatansız olmasaydı o devletin yasaları tarafından tanınacak haklar arasında bulunması gereklidir (12/II)".

80 RG. $25.10 .2014 / 29156$.

81 Hukuki Statü başlıklı madde şu şekildedir: "Her mültecinin bireysel statüsü daimi ikametgahının bulunduğu ülkenin 
bulunmaması halinde, oturduğu devletin hukuku uygulanacaktır. Bu halde, vatansız ve mülteciler için öncelikle Türkiye’nin taraf olduğu sözleşmeler dikkate alınacak; vatansız ve mülteciler bu sözleşmelerin kapsamında değil ise MÖHUK m.4/I-a bendine bakılacaktır.

\section{B. Yabancı Devlet Vatandaşı Kadının Türk Vatandaşı Erkekle Evliliğinde Iddet Müddeti Unsuru}

Türk vatandaşı erkek ve yabancı devlet vatandaşı kadının evlenmesi halinde evlenme ehliyet ve şartlarına uygulanacak hukuk MÖHUK md. 13 uyarınca tespit edilecektir. Yabancı devlet vatandaşı kadının evlenme ehliyet ve şartlarını tanzim eden milli hukukunda iddet müddeti düzenlenmemiş olabilir. Yabancı hukukta iddet müddetinin düzenlenmemiş olmasının Türk kamu düzenine aykırı olup olmadığ düşünüldüğünde, bu soruya olumsuz yanıt vermek gerekecektir ${ }^{82}$. Yabancı hukukun iddet müddetini hiç düzenlememiş veyahut çok kısa düzenlemiş olması MÖHUK md. 5 kapsamına girmeyecektir.

Kaldı ki, Nüfus Hizmetleri Uygulama Yönetmeliği’nin ${ }^{83} 23$. maddesi bu hususu ayrıca düzenlemiştir. Yönetmelik md. 23 uyarınca, kadın için üç yüz günlük bekleme süresi, boşanma veya evliliğin iptali kararının kesinleştiği tarihten, kocası ölen kadının iddet müddeti ise kocasının ölüm tarihinden itibaren hüküm ifade edecektir; ancak yabancı devlet vatandaşı kadının milli hukukunda bekleme süresi öngörülmemişse, evlendirme memurluklarınca bu süre dikkate alınamayacaktır. Ancak yabancı devlet vatandaşı olan kadının milli hukukunun iddet müddetini çok uzun bir süreye yaymış olması (veya iddet müddetinin kaldırılması davasının açılmasına imkân verilmeyerek doğum için beklenmesi gereken 300 günlük sürenin tamamlanmasını şart koşmak) kanımızca MÖHUK md. 5’e aykırıdır. Zira bu durum kapsamına giren boşanmış bir kadının, tek taraflı evlenme engeli sebebine istinaden yeniden evlenmesi engellenmiş olmakta, fakat boşandığı kocası hayatını herhangi bir kaideye bağlı kalmadan devam ettirebilmektedir.

Türkiye'de evlenmek isteyen yabancı devlet vatandaşı kadın, Evlenme Ehliyet Belgesi Verilmesine Dair Sözleşme'ye ${ }^{84}$ taraf ülkenin vatandaşı ise, kendi ülkesinin resmi makamlarınca hazırlanmış formül B adını taşıyan uluslararası evlenme ehliyet belgesini Türk makamlarına ibraz etmek zorundadır $^{85}$. Evlendirme Yönetmeliği’ninin ${ }^{86}$ 12. maddesi uyarınca, evlenme ehliyet belgesinin tarafların vatandaşlığı bulunduğu devlet makamlarından bizzat temin edilmesi aranmaktadır;

yasalarına veya eğer daimi ikametgahı yoksa, bulunduğu ülkenin yasalarına tabidir (12/I). Mültecinin önceden kazandığı ve bireysel statüsüyle ilgili haklara, özellikle evliliğe bağlı haklara, her Taraf Devlet tarafından, gerekirse bu devletin yasalarının gösterdiği koşulları yerine getirmek kaydıyla, söz konusu hakkın, kişi mülteci olmasaydı o devletin yasalarınca tanınacak haklar arasında bulunması durumunda, saygı gösterilecektir (12/II)".

82 Türk aile hukukundaki her düzenlemenin kanunlar ihtilafı kuralları bakımından emredici olmadığı yönünde bkz. Giray, Faruk Kerem, 4721 sayılı Türk Medeni Kanununda Yer Alan Aile Konutu Kavramının Kanunlar İhtilafı Hukuku Bakımından Değerlendirilmesi, MHB, 23/1-2, 2003, s. 483; Çelikel/Erdem, s. 236; Tekinalp, s. 140.

83 RG. 09.05.2020/31122.

84 RG. 29.04.1988/19799.

85 05.09.1980 tarihli Evlenme Ehliyet Belgesi Verilmesine Dair Sözleşme’yi imzalayan ülkeler Almanya, Avusturya, Belçika, İspanya, Yunanistan, İtalya, Lüksemburg, Hollanda, Portekiz, İsviçre, Türkiye ve Moldova’dır.

RG. 07.11.1985/18921. 
bunun mümkün olmaması halinde bu belge evlendirme memurları tarafından Genel Müdürlük aracıllğ̆ ile istenebilecektir. Yönetmelik md. 13 uyarınca, Yabancılar ve Uluslararası Koruma Kanunu kapsamındaki yabancılardan ikamet izni dışında Türkiye'de bulunan vatansız, mülteci, şartlı mülteci, ikincil koruma statüsünde bulunanlar ve uluslararası koruma başvuru sahipleri ile geçici koruma kapsamına alınan yabancıların müracaatları evlendirme memurları tarafından kabul edilecektir; bu kişilerin evlenme engellerinin bulunup bulunmadığı il göç idaresi müdürlüklerince tutulan dosyalarındaki bilgi ve belgelere göre il göç idaresi müdürlüklerince tespit edilerek evlenme ehliyet belgesi düzenlenecektir.

Çalışmamızda esas aldığımız ihtimallere göre, yabancı devlet vatandaşı kadın, süre şartına dâhil olmadan ve hâlihazırda yabancı devlet vatandaşı biyolojik babadan hamile olarak Türk vatandaşı erkekle evlenirse, çocuk evlilik birliği içerisinde dünyaya gelmiş olduğundan Türk vatandaşı kocanın soyuna bağlanacaktır ${ }^{87}$. Bu halde Türk vatandaşı kocanın soybağının reddine dair dava açması mümkün müdür? Şayet bu dava açılıp, koca ve çocuk arasındaki soybağı ilişkisi kesilirse, yabancı devlet vatandaşı ananın babalık davası açması söz konusu olabilir mi? Aşağıda bu iki temel ihtimal üzerinde durularak açılan davalarda yetkili mahkeme ve ihtilafa uygulanacak hukuk tespit edilmeye çalışlacaktır.

\section{Türk Maddi Hukukunda Soybağının Reddi ve Yabancılık Unsuru Taşıyan Soybağının Reddi Davasında Yetkili Türk Mahkemesi}

\section{a. Türk Medeni Kanunu Kapsamında Soybağının Reddi}

Türk hukukunda, koca ile çocuk arasında babalık karinesi uyarınca kurulan soybağı, gerçeği yansıtmayabilir ve çocuğun biyolojik babası babalık karinesi uyarınca baba sayılan erkek

87 Yargıtay 17. HD., E. 2014/11748, K. 09.07.2014, “Taraflar arasındaki nüfus kaydının düzeltilmesine ilişkin davada ... 4. Asliye Hukuk Mahkemesi ile ... 4. Aile Mahkemelerince ayrı ayrı görevsizlik kararı verilmesi nedeni ile yargı yerinin belirlenmesi için gönderilen dosya içindeki tüm belgeler incelendi, gereği düşünüldü: Dava, davalının nüfus kaydında baba adının düzeltilmesi istemine ilişkindir. Asliye Hukuk Mahkemesi, davanın nesebin düzeltilmesi istemine ilişkin olduğu gerekçesiyle görevsizlik kararı vermiştir. Aile Mahkemesi ise, anne ve baba adının düzeltilmesi talebinin soy bağına ilişkin olmadığı, nüfus kaydının düzeltilmesine ilişkin olduğu gerekçesiyle görevsizlik yönünde hüküm kurmuştur. Aile Mahkemeleri TMK.nun 282 ve devamı maddelerinde sınırlı olarak belirtilen soy bağının reddi (TMK'nun 286. vd.) babalık, tanıma, tanımanın iptali gibi davalara bakmakla görevlidir. Somut olayda davaname ile A’nın gayriresmi birlikteliğinden olan oğlu Ş’yi boşandıktan sonra iddet müddeti içerisinde nüfusa kaydettirmesi nedeniyle eski eşi adına nüfusa kaydedildiği, gerçekte babasının A.K. olduğu iddiasıyla Ş’nin nüfus kaydının düzeltilmesini talep edilmiştir. Davanın kabul edilmesi halinde davalının baba adının değiştirilmesinin yanında nüfusta babası ile soy bağı kurulacağından, dava bu niteliği itibariyle bir nesep davasıdır. Soy bağı hukuku ile ilgili davalar 4787 sayılı Aile Mahkemelerinin görev ve yargılama usullerine dair kanunun 4. maddesinde gösterilen davalardan olup TMK.'nun 282 vd. maddelerinde düzenlenen soy bağı kurulmasıyla ilgili olan bu davanın Aile Mahkemesinde görülüp sonuçlandırılması gerekir; (Erişim: 04.03.2021, www.legalbank.net); Yargıtay 11. Ceza Dairesi, E. 2017/14034, K. 13.12.2017, “Temyiz dışı sanık ...un katılan ... ile resmi olarak evli olduğu ancak boşanma davası devam ettiği, süreç içinde sanık ... ile gayrı resmi birliktelik yaşadığı, boşanmanın 25.01.2012'de kesinleştiği, 20.04.2012 tarihinde ... isminde bir çocuğun dünyaya geldiği, çocuğun babası ... olmasına rağmen iddet müddeti içinde doğan ...’n evlilik birlikteliği içinde doğmuş gibi nüfusa baba hanesi ... olarak kayıt edilmesinden ibaret eylemde; sanık ....in, ... yeni boşandığı ve kanunun aradığı süreyi doldurmadığı için resmi nikah yapamadıklarını, birlikte yaşadıkları süre içerisinde ... isminde bir çocuklarının olduğunu, çocuğunun rahatsızlandığını, tedavi işlemleri için nüfus cüzdanı gerekli olduğunu, bu nedenle nüfusa ...’n baba ismini daha sonra değiştirmek üzere ... olarak kaydettirmek zorunda kaldıklarını..., (Erişim: 04.03.2021, www.legalbank.net). 
olmayabilir $^{88}$. Evlilik devam ederken veya evliliğin sona ermesinden itibaren üçyüz gün içerisinde doğan çocuğun babası kocadır. (TMK md. 285). Çocuğun ana rahmine düştüğü tarih itibariyle taraflar henüz evli olmamakla birlikte doğum zamanında evlenmişlerse, hatta doğum evliliğin hemen öncesinde gerçekleşmiş olsa da çocuğun babasının koca olduğu kabul edilmektedir ${ }^{89}$. Kanun koyucu, çocuğun ana rahmine düştügü tarihin evliliğin öncesinde veya sonrasında olmasına bakmamış, doğum anında ananın evli olduğu kocayı baba kabul etmiştir ${ }^{90}$. TMK md. 292 uyarınca, tarafların doğumdan sonra evlenmesi halinde ananın evlendiği kişinin çocuğun babası olduğundan hareketle, eşlerin bu konuda yapacağı bildirim çocukla koca arasında soybağının kurulması için yeterli görülmüştür ${ }^{91}$. Dolayısıyla kanun koyucu, çocuğun üstün yararını gözetmiş; biyolojik baba olsun veya olmasın, ananın evli olduğu kocayla çocuk arasında soybağını kurarak çocuğu hukuki ve sosyal yükten kurtarmışıır' ${ }^{92}$.

TMK md. 285'te düzenlenen babalık karinesinin ortadan kaldırılması, soybağının reddi davasıyla mümkündür ${ }^{93}$. TMK md. 286 uyarınca, koca ana ve çocuğa karşı soybağının reddi davası açarak babalık karinesini çürütebileceği gibi, çocuk da ana ve kocaya karşı dava açma hakkına sahiptir. Bozucu yenilik doğuran hak niteliğinde olan soybağının reddi ancak dava yoluyla kullanılabilmektedir ve davayı açma hakkı davacı bakımından kişiye sıkı sıkıya bağlı haklardan kabul edilmektedir ${ }^{94}$. Soybağının reddi kararıyla, çocuk ile koca arasındaki soybağı ilişkisi geriye yönelik olarak ortadan kalkacaktır ${ }^{95}$. Soybağının reddi davası hak düşürücü süreye tabidir. Koca, çocuğun kendisinden olmadığını öğrendikten sonra bir yıllık hak düşürücü süre içerisinde davasını açabilecektir; bu süre içerisinde koca ölürse veya ölüm karinesi söz konusu ise, ölüm tarihinin hak düşürücü süre içerisinde olup olmadığ tespit edilecektir ve diğer ilgililerin dava açma hakkı ölüm tarihi dikkate alınarak başlayacaktır ${ }^{96}$. Çocuk ise ergin olduğu tarihten itibaren başlayarak en geç bir yıl içerisinde dava açmak zorunda olup, haklı bir sebebe dayanan gecikme varsa, bir yıllık süre bu sebebin ortaya kalktığı tarihten itibaren işlemeye başlayacaktır (TMK md. 289). Dava neticesinde, biyolojik babaya soybağını kurma imkânı (babalık davası veya tanıma usulü sayesinde) sağlanacaktır ${ }^{97}$.

88 Demirbaş, s. 8; Altıner Yolcu, Fatma Zeynep, Soybağının Reddi Davasında Biyolojik Baba, İstanbul Aydın Üniversitesi Hukuk Fakültesi Dergisi, 6/2-2020, s. 251.

89 Kutoğlu, Tuba, Türk Mevzuatında ve İçtihatlarında Babalık Hükmü, Dokuz Eylül Üniversitesi Hukuk Fakültesi Dergisi, Cilt: 12, 2010, s. 949.

90 Kutoğlu, s. 949.

91 Kutoğlu, s. 949.

92 Kutoğlu, s. 949.

93 Demirbaş, s. 8; Gümüş, Alper M., Koca, Çocuk ve Ergin Olmayan Çocuğa Atanan Kayyım Dışındaki Diğer İlgililerin (Kocanın Ana ve Babası ile Altsoyunun, Baba Olduğunu İddia Eden Kişinin, Annenin (!)) Soybağının Reddi Davası Açma Hakkı (TMK md. 291/I), Prof. Dr. Mustafa Durala Armağan, İstanbul 2013, s. 568.

94 Demirbaş, s. 8 vd.; Altıner Yolcu, s. 252, 253.

95 Altıner Yolcu, s. 257; Öztan, s. 898.

96 Gümüş, s. 575; Altıner Yolcu, s. 254.

97 Altıner Yolcu, s. 252. 


\section{b. Yabancılık Unsuru İçeren Soybağının Reddi Davasında Yetkili Mahkemenin Tesisi}

Türk vatandaşı erkek, biyolojik babadan olan çocukla soybağını kesmek için soybağının reddi davası açmak isteyebilir. Soybağının reddi davası Türkiyede açılacaksa, yabancılık unsuru içeren bu ihtilafta öncelikle yetkili mahkemenin tespit edilmesi gerekmektedir. Türk mahkemelerinin milletlerarası yetkisini düzenleyen genel kural MÖHUK md. 40’ta yer almaktadır. MÖHUK md. 40 uyarınca, Türk mahkemelerinin milletlerarası yetkisi iç hukukun yetki kaideleri vasıtasılla belirlenecektir. Bir görüş uyarınca, MÖHUK’ta yer alan özel kuralların varlığı halinde, genel kural olan md. 40’a değil, özel kurala gidilmesi gerektiği kabul edilmektedir ${ }^{98}$. Soybağının reddi davası, Türklerin kişi hallerine ilişkin davalarda yetkiyi tesis eden MÖHUK md. 41'in uygulama alanına girmektedir. MÖHUK md. 41'de dava kelimesi yer alsa da, maddenin kapsamında çekişmesiz yargı işlerinin de gireceğini düşünmekteyiz ${ }^{99}$. MÖHUK md. 41 uyarınca, Türk vatandaşlarının kişi hallerine ilişkin davaları, yabancı ülke mahkemelerinde açılmadığı veya açılamadığı takdirde Türkiye’de yer itibariyle yetkili mahkemede (TMK md. 283, HMK md. 6, HMK md. 9), bulunmaması halinde ilgilinin sakin olduğu yer, Türkiye'de sakin değilse Türkiye'deki son yerleşim yeri mahkemesinde, o da bulunmadığı takdirde Ankara, İstanbul veya İzmir mahkemelerinden birinde görülecektir. MÖHUK md. 41, yer itibarıla yetki tesisinde iç hukuk kaidelerine atıfta bulunmaktadır; buna göre iç hukukta yetkiyi düzenleyen kurala göre diğer kanunlarda yer alan yetkiye dair hükümler saklı kalmak şartıyla, HMK md. 6, HMK md. 9 ve TMK md. 238'e gidilebilecektir ${ }^{100}$.

Yetkili mahkemenin tayini maddede izlenilen basamaklar sayesinde yapilacak; bir basamakta milletlerarası yetkiyi haiz Türk mahkemesinin hazır bulunması halinde bir sonraki basamağa geçilemeyecek $^{101}$, dolayısıyla alternatifli bir usul izlenmeyecektir. Kanun koyucu en son ihtimalde Ankara, İstanbul ve İzmir mahkemelerine gidilebileceğini belirtirken, maddenin kapsamına giren ihtilaflarda Türkiye'de mutlaka yetkili bir mahkemenin bulunmasını hedeflemiştir. Bu sayede, davanın tarafı olan Türk vatandaşının kişi hallerine ilişkin ihtilafının neticelendirilmesi amaçlanmaktadır. MÖHUK md. 41 Türkiye'de yetkili mahkemenin hazır bulunmasını hedeflerken münhasırlık niteliğini de bu kapsamda taşımakta mıdır? Bu soruya olumsuz yanıt verilmelidir; zira madde metninde yabancı ülkede dava açılmasının mümkün olduğu zaten belirtilmektedir ${ }^{102}$. MÖHUK md. 41 uyarınca soybağının reddi davasını Türkiye’de dava açabilmek için yabancı ülke mahkemesinde aynı ihtilafa dair dava açılmamış olması veya yabancı mahkemenin yer itibarıyla yetkisiz olmasından dolayı davanın açılamamış olması gerekir ${ }^{103}$. Bu halde, davanın yabancı mahkemede açılmış olması

98 MÖHUK md. 40’ın yanında düzenlenen özel yetki kurallarının genel kuralın yanında tamamlayıcılık fonksiyonuna dair tartışmalar için bkz. Nomer, s. 473; Özel, Sibel, Yabancılık Unsuru Taşıyan Bireysel İş Sözleşmelerinden Kaynaklanan Uyuşmazlıklarda Türk Mahkemelerinin Yetkisi: MÖHUK m.44, Bahçeşehir Üniversitesi Hukuk Fakültesi Dergisi, 179/2019, s. 1351 vd.; Akınc1/Gökyayla, s. 129. Aksi görüş ve gerekçeleri için bkz. Tan Dehmen, s. 188 vd.

99 Aynı yönde Tekinalp, s. 410; Tan Dehmen, Mine, Türk Vatandaşlarının Kişi Hallerine İlişkin Davalar Bakımından 5718 Sayılı MÖHUK’ta Kabul Edilen Yetki Kuralı, MHB, Cilt:33, Sayı: 1, 2013, s. 174.

100 Özkan, Işı1/Tütüncübaşı, Uğur, Uluslararası Usul Hukuku, Ankara 2017, s. 82.

101 Erten, Rifat, Türklerin Kişi Hallerine İlişkin Davalarda Türk Mahkemelerinin Milletlerarası Yetkisi, Ankara 2017, s. 127, 155 vd; Özkan/Tütüncübaşı, s. 83.

102 Nomer, s. $473 \mathrm{vd}$.

103 MÖHUK md. 41'in milletlerarası derdestlikle ilgili değerlendirilmesi için bkz. Akıncı, s. 50 vd.; Tiryakioğlu, Bilgin, Türklerin Kişi Hallerine İlişkin Davalarda Türk Mahkemelerinin Milletlerarası Yetkisi, Tuğrul Arat’a Armağan, Ankara 
Türk mahkemelerinin yetkisinin doğmamasına neden olacaktır ${ }^{104}$. Bir görüş uyarınca, derdestlik itirazı yapılabilmesi için davanın yabancı ülkede açılmış ve görülmekte olması yeterli ve gerekli kabul edilmektedir ${ }^{105}$. Diğger görüş, maddenin lafzına bakıldığında, davanın Türk mahkemelerinde görülmesi için yabancı mahkemede açılmış olmasının yeterli olduğunu; halihazırda görülmekte olmasına lüzum olmadığı ifade etmektedir ${ }^{106}$. Kişinin kendi isteğiyle yaşadığı ülkede dava açmaması, açtığı davada ilgili yabancı mahkemenin kendisini yetkisiz gördüğü için davaya bakmamış olması veyahut başka bir fiili/hukuki imkânsızlık halinde de MÖHUK md. 41'in dava açılmamış olma şartının karşılandığ ${ }_{1}$ ileri sürülmektedir ${ }^{107}$.

İhtilafımızda davacı erkek Türk vatandaşıdır; ancak davanın taraflarından herhangi birinin dava açıldı ̆̆ 1 tarihte Türk vatandaşı olması yeterlidir ${ }^{108}$. Vatansızlar, 5901 sayılı Türk Vatandaşlık Kanunu ${ }^{109}$ md. 28 kapsamındakiler ve mülteciler Türk vatandaşı kavramı altında değerlendirilemez ${ }^{110}$.

\section{c. Yabancılık Unsuru İçeren Soybağının Reddi Davasında Uygulanacak Kanunlar Ihtilafı Kaidesinin Tespiti}

Soybağının reddi davasında uygulanacak hukuk soybağının kurulması başlıklı MÖHUK md. 16/II uyarınca tespit edilecektir. Davanın kim tarafından kimlere karşı açılabileceği, davada ispat yükünün kime ait olduğu gibi hususlar MÖHUK md. 16/II'nin kapsamına girmektedir ${ }^{111}$. MÖHUK md. 16/II uyarınca, soybağı hangi hukuka göre kurulmuşsa iptali de o hukuka tabidir.

MÖHUK md. 16/I uyarınca, soybağının kuruluşu, çocuğun doğum anındaki milli hukukuna, kurulamaması halinde çocuğun mutad meskeni hukukuna tabidir. Soybağı bu hukuklara göre kurulamıyorsa, ananın veya babanın, çocuğun doğumu anındaki milli hukuklarına, bunlara göre kurulamaması halinde ana ve babanın, çocuğun doğumu anındaki müşterek mutad mesken hukukuna, buna göre de kurulamıyorsa çocuğun doğum yeri hukukuna tabi olarak kurulacaktır ${ }^{112}$.

2012, s. 1145.

104 Dava açılması tabirinin nasıl yorumlanması konusundaki tartışmalar için bkz. Tan Dehmen, s. 178; Nomer, s. 474 vd.; Akıncı, s. 51; Tiryakioğlu, 1155 vd.; Çelikel/Erdem, s. 617 vd.

105 Nomer, s. 474.

106 Tan Dehmen, s. 178.

107 Özkan/Tütüncübaşı, s. 80.

108 Tiryakioğlu, s. 1145; Nomer, s. 472; Şanlı/Esen/Figanmeşe, s. 489; Tan Dehmen, s. 172; Aybay/Dardağan, 55; Çelikel/ Erdem, s. 617 vd. Davanın tarafının Türk vatandaşlığından başka bir vatandaşlığa daha sahip olması, Türk vatandaşlığının dikkate alınmayacağı anlamına gelmemelidir; bu kapsamda mülga MÖHUK md. 28 bakımından Türk vatandaşlığının nazara alınmasını savunan görüş için bkz. Akıncı, Ziya, Milletlerarası Usul Hukukunda Yetki Sözleşmesine Dayanan Milletlerarası Derdestlik, Ankara, 2002, s. 48. Aynı yönde bkz. Nomer, s. 472 vd.; Tan Dehmen, s. 173.

109 RG. 12.06.2009/27256.

110 Erten, s. 83, 92 vd.; Tan Dehmen, s. 173; Özkan/Tütüncübaşı, s. 80.

111 Can/Toker, s. 219.

112 Yargıtay 2. HD., E. 2008/4290, K. 02.06.2009, “Soybağının kuruluşu, çocuğun doğum anındaki milli hukukuna, kurulamaması halinde çocuğun mutad meskeni hukukuna tabidir. Soybağı bu hukuklara göre kurulamıyorsa, ananın veya babanın, çocuğun doğumu anındaki milli hukuklarına, bunlara göre kurulamaması halinde ana ve babanın, çocuğun doğumu anındaki müşterek mutat mesken hukukuna, buna göre de kurulamıyorsa çocuğun doğum yeri hukukuna tabi olarak kurulur. Soybağı hangi hukuka göre kurulmuşsa iptali de o hukuka tabidir. Soybağı hükümleri, soybağını 
MÖHUK md. 16/I düzenlemesinde, çocuğun menfaatine uygun hukukun uygulama alanı bulması hedeflenmiştir ${ }^{113}$. Doğum anındaki hukukun belirlenmesi için çocuğun doğum anında vatandaşlı̆̆ının olması gerekmektedir; çocuk kan esasına göre vatandaşılk kazanamamış ve toprak esasına göre de bir vatandaşlık bağı kurulamamış ise çocuğun milli hukuku bulunmayabilir ${ }^{114}$. Bir görüş, ilk basamakta yer alan milli hukukun tespiti için soybağının kurulması gerektiğini, soybağının kurulması için de (en azından toprak esasının uygulama alanı bulmadığı hallerde) çocuğun milli hukukunun belirlenmesinin gerektiğini, bu şekilde bir kısır döngüye girildiğini ifade etmektedirr ${ }^{115}$. İkinci basamakta çocuğun mutad meskeni hukukunun uygulanması gerektiği düzenlenmiştir. Çocuğun hangi andaki mutad mesken hukukunun dikkate alınacağı madde metninde açıkça zikredilmemiş olsa da, bir görüş burada çocuğun doğum anındaki mutad mesken hukukunun kastedildiği düşünülmektedir ${ }^{116}$; karşı görüs ise MÖHUK md. 3'ten hareketle dava anının esas alınması gerektiğini savunmaktadır ${ }^{117}$. Burada ilk basamakta yer alan zamanı işaret eden ifadenin (çocuğun doğumu anı), ikinci basamağı da kapsayacağından kanun koyucu tarafından tekrar edilmediği düşünülebilir; ancak dava açıldığında tespit edilmesi gereken bu halin MÖHUK md. 3 uyarınca dava anı dikkate alınarak sabitlenmesi fikrine

kuran hukuka tabidir. Ancak ana, baba ve çocuğun müşterek milli hukuku bulunuyorsa, soybağının hükümlerine o hukuk, bulunmadığı takdirde müşterek mutat mesken hukuku uygulanır. KARAR : Davacı dava dilekçesinde; tarafların Hamburg Asliye Hukuk Mahkemesinin 13.03.2003 günlü kararı ile boşandıklarını, kararın aynı gün kesinleştiğini, kesinleşmeden sonra davacının 02.01.2004 tarihinde Hamburg'da Yağmur Feride’yi doğurduğunu, ancak doğumun boşanmadan sonraki iddet müddeti içinde gerçekleştiğinden, çocuğun babası olarak davacının boşandığı eşi yani davalının gösterildiğini, davacı bu yanlışlığın giderilmesi için Hamburg-St Georg Asliye Hukuk mahkemesinde nesebin reddi davası açtığını, mahkemenin 15.08.2005 tarihinde davanın kabulüne küçük Yağmur Feride’nin davalının çocuğu olmadığına nesebin reddine karar verdiğini, kararın 15.08.2005 tarihinde kesinleştiğini belirterek, kararın tenfizini talep etmiştir. Mahkemece davada küçüğün kayyımla temsil edilmediği ve Türk Medeni Kanunu yerine Alman Medeni Kanununun uygulanmasının kamu düzenine aykırılık teşkil ettiğini belirterek talebin reddine karar vermiştir. 5718 sayılı Milletlerarası Özel Hukuk ve Usul Hukuku Hakkındaki Kanunun 16. maddesi "Soybağının kuruluşu, çocuğun doğum anındaki milli hukukuna, kurulamaması halinde çocuğun mutad meskeni hukukuna tabidir. Soybağı bu hukuklara göre kurulamıyorsa, ananın veya babanın, çocuğun doğumu anındaki milli hukuklarına, bunlara göre kurulamaması halinde ana ve babanın, çocuğun doğumu anındaki müşterek mutat mesken hukukuna, buna göre de kurulamıyorsa çocuğun doğum yeri hukukuna tabi olarak kurulur. Soybağı hangi hukuka göre kurulmuşsa iptali de o hukuka tabidir" hükmünü içerdiği gibi 17. madde de ise; "Soybağı hükümleri, soybağını kuran hukuka tabidir. Ancak ana, baba ve çocuğun müşterek milli hukuku bulunuyorsa, soybağının hükümlerine o hukuk, bulunmadığı takdirde müşterek mutat mesken hukuku uygulanır" hükmünü içermektedir. 5718 sayılı yasanın 7. maddesi ise "Hukuki işlemler, yapıldıkları ülke hukukunun veya o hukuki işlemin esası hakkında yetkili olan hukukun maddi hukuk hükümlerinin öngördüğü şekle uygun olarak yapılabilir" demektedir. Açıklanan sebeple davanın kabulü gerekirken yazılı şekilde hüküm kurulması usul ve yasaya aykırıdır. Sonuç: Temyiz edilen hükmün yukarıda gösterilen sebeple bozulmasına, temyiz peşin harcının yatırana geri verilmesine, işbu kararın tebliğinden itibaren 15 gün içinde karar düzeltme yolu açı olmak üzere, 02.06.2009 gününde oyçokluğuyla karar verildi. Karşı Oy: Dosyadaki yazılara kararın dayandığı delillerle kanuna uygun sebeplere ve özellikle delillerin takdirinde bir yanlışlı görülmemesine göre yerinde bulunmayan temyiz isteğinin reddiyle usul ve kanuna uygun olan hükmün onanması gerektiği düşüncesiyle sayın çoğunluğun kararına katılmıyoruz", (Erişim: 04.03.2021, www.legalbank.net).

113 Dardağan Kibar, Esra, Uluslararası Özel Hukukta Soybağı ve Velayete İlişkin Sorunlar, GÜHFD, Prof. Dr. Ata Sakmar’a Armağan, 2011/I, s. 543; Doğan, s. 348 vd.

114 Şanll/Esen/Ataman Figanmeşe, s. 172 vd.

115 Dardağan, Kibar, s. 546.

116 Çelikel/Erdem, s. 273; Tekinalp, s. 178. Ayrıca, 5718 sayılı MÖHUK yürürülüğe girdiğinde statü değişikliği halinde çocuğun lehine netice doğuracak eski veya yeni hukukun uygulanmasına imkan tanıyacak düzenleme getirilmesi hakkında bkz. Uyanık Çavuşoğlu, Ayfer, Yeni MÖHUK’a Göre Soybağı İlişkisine Uygulanacak Hukuk Sorunu, Maltepe Üniversitesi Hukuk Fakültesi Dergisi, 2008/2, s. 318-319.

117 Şanlı/Esen/Ataman Figanmeșe, s. 174; Güngör, s. 147; Can/Toker, s. 217. 
katılmaktayız ${ }^{118}$. Soybağı MÖHUK md. 16'da yer alan bu hukuklara göre kurulamıyorsa, ananın veya babanın, çocuğun doğumu anındaki milli hukuklarına, bunlara göre kurulamaması halinde ana ve babanın, çocuğun doğumu anındaki müşterek mutad mesken hukukuna, buna göre de kurulamıyorsa çocuğun doğum yeri hukukuna tabi olarak kurulacaktır. Ana ve babanın çocuğun doğumu anındaki milli hukukları arasında bir öncelik tanınmamış, aksine soybağının kurulması bakımından elverişli olan bağlama kriterinin dikkate alınması tercih edilmiştir ${ }^{119}$. Soybağının en son basamakta yer alan doğum yeri hukukuna göre kurulması hukuki ilişki ile hiçbir bağlantısı olmayan tesadüfi bir hukuka gidilmesi yönüyle eleştirilse de, soybağının kurulması adına bazen bu hukuka dahi gitmede sakınca olmayacağ 1 ifade edilmektedir ${ }^{120}$.

MÖHUK md. 16/II uyarınca ulaşılan MÖHUK md. 16/I, basamaklı bir sistem benimsemiştir. Bir basamak tüketilmeden bir sonraki basamağa geçilemeyecektir; yani ilk basamak uyarınca soybağının kurulması mümkün değilse bir sonraki basamağa geçilmelidir. Kanun koyucunun gayesi şüphesiz ki çocuğun soybağını kurmaktır; ancak kanımızca uygulanacak hukuka basamaklı sistemle erişilmesi elverişsizliğe neden olabilir. Örneğin ana baba bakımından soybağını kuran bir hukukun bulunması halinde, çocuğun anası ve babası bakımından soybağının tek bir hukuk uyarınca kurulması sağlanabilir; böylelikle çocuğun ana bakımından soybağını kuran hukuk ile baba bakımından soybağını kuran hukukun farklı olması ihtimali bertaraf edilebilirdi ${ }^{121}$. Katıldığımız görüş uyarınca, uygulanacak hukuka erişilmesi yolunda basamaklı sistem yerine alternatifli bir seçim hakkı sunulsaydı çocuğun menfaatinin sağlanması için daha uygun olan hukuka ulaşılabilirdi ${ }^{122}$. Böyle bir uygulamayla, ihtilafa uygulanacak hukuka erişilmesinde süre sıkıntısının da önüne geçilebilirdi. Doktrinde, kanunda kabul edilen basamaklı kanunlar ihtilafı kuralı yerine alternatifli kanunlar ihtilafı kuralının kabul edilmesinin soybağının kurulma amacı ile daha uyumlu olacağının savunulması eleştirilmektedir; zira kanunda yer alan düzenlemenin basamaklı veya alternatifli olmasının uygulanacak hukuk açısından önemli olacağı işaret edilmektedir ${ }^{123}$. Bu görüş uyarınca, kanun koyucunun amacı soybağını kurulmaktır; içerik olarak daha elverişli olan bir hukukun soybağının kurulmasında uygulama alanı bulmasını sağlamak değildir ${ }^{124}$. Diğer bir görüş, hükmün esas gayesinin soybağının kurulmasında çocuk lehine en uygun olan hukukun uygulanmasını hedefleyen bir sistem (favor legitimitatis) olduğu sonucuna varmaktadır ${ }^{125}$. Bu düşünce uyarınca, çocuğun menfaati, soybağının kurulmasındadır, ancak bağlanma düzeninde de çocuğun menfaatine

118 Şanlı/Esen/Ataman Figanmeşe, s. 174; Güngör, s. 147; Can/Toker, s. 217.

119 Uyanık Çavuşoğlu, s. 317.

120 Öztekin Gelgel, Öztekin Gelgel, Günseli, Devletler Özel Hukukunda Velayet, Çocuk Kaçırmaları, Evlat Edinmeye İlişkin Problemler, İstanbul Ticaret Üniversitesi Sosyal Bilimler Dergisi, Yıl: 4/8, 2005/2, s. 121. Çocuğun doğum yeri hukuku yerine lex fori’nin uygulanması düşüncesiyle ilgili tartışmalar için bkz., Uyanık Çavuşoğlu, s. 318.

121 Şanlı/Esen/Ataman Figanmeşe, s. 175.

122 Dardağan s. 545. Bu husustaki tartışmalar için bkz. Nomer, s. 271 vd.; Özgenç, Zeynep, Velâyete Uygulanacak Hukukun Tespitinde Kamu Düzeni Müdahalesine İlişkin Değerlendirmeler, Ankara Hacı Bayram Veli Üniversitesi Hukuk Fakültesi Dergisi, Sayı: 1, XXII/ 2018, s. 15; Aybay/Dardağan, s. 219; Doğan, s. 349. Karşı görüş için bkz. Akıncı/Demir Gökyayla, s. 122 .

123 Doğan, s. 349.

124 Doğan, s. 349.

125 Nomer, s. 271. 
en uygun olan hukukun hedeflendiği sonucuna varılmaktadır ${ }^{126}$. Bu nedenle de, bağlanma noktalarının hangi sırayla dikkate alınması bu görüş uyarınca önem taşımaktadır.

Soybağının reddi davasında, kanun koyucu "soybağının kuruluş anı" ile bağlı kalmaktadır; yani soybağının kurulmasını sağlayan hukuku tespite yarayan bağlama noktası değişmiş bile olsa bu husus soybağının reddi davasında dikkate alınmayacaktır. Bu nedenle örneğin vasfını yitirmiş olan ve tarafların ilgisinin kalmadığı müșterek mutad mesken hukuku, soybağının reddi davasında uygulanmak zorunda kalacaktır ${ }^{127}$. Kanun koyucunun endişesi, kuruluş ve iptali aynı hukuk kapsamında tutmak, farklı hukuk sistemlerinin çakışmasını önlemektir. Bu noktada bir tartışma açmak istiyoruz. Dikkat çekmek istediğimiz husus, kanun koyucunun atfı dikkate alıp almadığı meselesidir. Örneğin soybağ hukukuna göre kurulmuşsa, bu hukuk da Alman hukuku ise soybağının reddi davası Alman hukuku uyarınca nihayete erdirilecektir ${ }^{128}$. Ancak sadece bağlama noktasından hareket ettiğimizde ve maddi hukukta değişiklik yapılmış ise, atıf bizi farklı bir hukuka götürebilir. Bu halde sürprizlere açık bir halde soybağının reddi davasında uygulanacak hukuk tespit edilecektir. Kanımızca, çocuğun üstün yararının korunmasına hizmet açısından soybağı hangi devletin maddi hukukuna göre kurulduysa, red davasında da o devletin maddi hukukunun ihtilafa uygulanması gerekmektedir; örneğin müşterek mutad mesken hukuku işaret ettiği için Yunan hukukuna göre kurulan soybağı, artık müşterek mutad mesken hukuku dikkate alınarak değil, soybağı kurulurken ihtilafa uygulanan hukuk olduğu için soybağının reddi davasında uygulanmalıdır ve soybağının reddi davasında Yunan hukuku uygulanmalıdır.

Doktrinde, MÖHUK md. 16'nın amacının ve kaleme alınış biçiminin, MÖHUK md. 2/III'te yer alan açık hükme rağmen atıf uygulamasına uygun olmadığı savunulmaktadır ${ }^{129}$. Şayet bağlama noktasına göre tespit edilen hukukun maddi hukuk kaidelerine göre istenen sonuç elde ediliyorsa, iade atfın ve devam atfın dikkate alınmamasına ihtiyaç olmadığı, MÖHUK md. 2/III'ün amaçsal yoruma tabi tutulması gerektiği, aksi düşüncenin MÖHUK md. 16’nın konuluş gayesine aykırı olduğu ifade edilmektedir ${ }^{130}$. Özetle, MÖHUK md. 16 uyarınca soybağ ilişkisini kuracak maddi hukuka erişildiğinde, artık bu hukukun kanunlar ihtilafı kaidelerinin dikkate alınmasının maddenin gayesine uygun düşmeyeceği, bu nedenle iade atfın ve devam eden atfın zımnen reddedildiği ifade edilmektedir ${ }^{131}$. Sunulan gerekçeler ışığında, soybağının kurulmasını ve reddini düzenleyen ihtilaflarda atfın dikkate alınmaması gerektiğini düşünmekteyiz. Karşıt görüş, soybağına dair kaidelerde atfın dikkate alınması gerektiğini ileri sürmektedir ${ }^{132}$. Ancak bu görüş uyarınca, üzerinde önemle durulması gereken esas husus soybağına ilişkin kanunlar ihtilafı kurallarının amacıdır ${ }^{133}$. Bu

126 Nomer, s. 271.

127 Şanlı/Esen/Ataman Figanmeşe, s. 182; Nomer, s. 280; Aybay/Dardağan, s. 219.

128 Ayrica bkz. Güngör, s. 148.

129 Güngör, s. 148; Can/Toker, Milletlerarası Özel Hukuk, Ankara 2016, s. 103.

130 Uyanık Çavuşoğlu, s. 319; Dardağan Kibar, s. 550.

131 Nomer, s. 156; Şanlı/Esen/Ataman Figanmeşe, s. 65; Doğan, s. 236. Aksi görüş için bkz. Tekinalp, s. 39.

132 Uyanık Çavuşoğlu, s. 319.

133 Uyanık Çavuşoğlu, s. 319. 
amaç, çocuğun soybağını kurmayı hedeflemektedir ${ }^{134}$. Kanunlar ihtilafı kuralları vasıtasıyla tespit edilen yabancı hukuk çocuk ile baba arasında soybağı kurulabiliyorsa, bu durumun dikkate alınması gerektiği; devam eden atıf sonucunda ulaşılan hukuk örneğin baba ile çocuk arasında soybağı ilişkisini kurmuyorsa, dikkate alınmaması gerektiği bu görüş tarafından ileri sürülmektedir ${ }^{135}$.

\section{Babalık Davası}

\section{a. Türk Medeni Kanunu Kapsamında Babalık Davası}

Bilindiği üzere, milletlerarası sözleşmeler ve mevzuatımız kapsamında çocuğun korunmaya muhtaç olduğundan hareket edilerek çocuğun üstün yararı korunmaya çalışılmaktadır ${ }^{136}$. Çocuğun soybağının kurulmasında da aynı ilkeden hareket edilmektedir. TMK md. 295/III, bu ilke kapsamında babalık davasının açılmasının ana kriterini belirlemiştir: "Başka bir erkek ile soybağı bulunan çocuk, bu bağ geçersiz kılınmadıkça tanınamaz”. Anasına soybağı ile bağlı olan çocuk, bir erkeğe soybağ ile bağlıyken başka bir erkeğe soybağı ile bağlanamaz ${ }^{137}$. Bu dava, soybağının doğum anında veya sonradan kurulamamış olması hallerinde açılabilecektir ${ }^{138}$. Evlilik dışı ilişkiden dünyaya gelen çocuğun babası olduğunu iddia eden erkeğin yenilik doğuran statü niteliğindeki babalık davası açma hakkı olup olmadığı sorusuna olumsuz yanıt vermek gerekecektir ${ }^{139}$; zira TMK kimlerin babalık davasını açabileceğini saymıştır: TMK md. 301 uyarınca, çocuk ile baba arasındaki soybağının mahkemece belirlenmesini ana ve çocuk isteyebilecektir ${ }^{140}$. Yabancı devlet vatandaşı kadının açtığı babalık davasında, davalı yabancı devlet vatandaşı erkeğin biyolojik baba olduğunun ispatlanması halinde hâkim ilgilinin baba olduğuna karar verecektir. Dava, çocuğun ana rahmine düşmesinden

134 Uyanık Çavuşoğlu, s. 319.

135 Uyanık Çavuşoğlu, s. 319.

136 Tanrıbilir, Feriha Bilge, Çocuk Haklarının Uluslararası Korunması ve Koruma Mekanizmaları, Ankara 2011, s. 51 vd.

137 Dural, Mustafa/Öğ̈̈z, Tufan/Gümüş, Alper, Türk Özel Hukuku, Cilt: 3, Aile Hukuku, İstanbul 2005, s. 471; Oğuzman, Kemal/Dural, Mustafa, Aile Hukuku, İstanbul 2001, s. 337; Demirbaş, Feride, Baba İle Çocuk Arasındaki Soybağına İlişkin Davalarda Davacı Olabilecek Kişiler, Ankara Hacı Bayram Veli Üniversitesi Hukuk Fakültesi Dergisi, Cilt: XXII, Sayı: 3, 2018, s. 5.

138 Demirbaş, s. 5.

139 Erkeğe babalık davasını açma hakkı verilmemesi bir hak kaybı olarak değerlendirilmemekte; zira babalık davasıyla aynı neticeleri doğuran tanıma kurumu ile aynı neticeye ulaşabileceği belirtilmiştir; Oğuzman/Dural, s. 337, 339; Akıntürk, Turgut, Türk Medeni Hukuku, Cilt: 2, Aile Hukuku, İstanbul 2006, s. 370, 373. Feyzioğlu, Feyzi Necmettin, Aile Hukuku, İstanbul 1996, s. 549. Yargıtay 2. HD., E. 2012/16001, K.: 01.10.2012, “Davacı evlilik dışı ilişkiden doğan 2009 doğumlu N...in kendi çocuğu olduğunu ileri sürerek soybağının kurulmasını ve çocukla arasında kişisel ilişki tesisini talep etmiş; ilk oturumda, mahkemece çocuğun başka bir erkekle soybağı bulunduğu ve bu geçersiz kılınmadıkça çocuğun tanınamayacağı gerekçesiyle davanın reddine karar verilmiştir. Mahkemenin ret gerekçesi doğru ise de; davadan önce mevcut soybağ 1 ilişkisini kaldırmaya yönelik olarak baba (koca) tarafından K. 3. Aile Mahkemesinde soybağının reddi davası açıldğı ve halen derdest olduğu anlaşılmaktadır. Bu durumda, mahkemece yapılacak iş; belirtilen K. 3. Aile Mahkemesindeki soybağının reddine ilişkin dava sonucunun bekletici sorun yapılması; dava reddedilip kesinleştiği taktirde, bu davanın da reddedilmesi; dava kabul edilip mevcut soybağının reddi kararı kesinleştiği taktirde ise, taraflara delillerini bildirmek için süre verilmesi, gösterdikleri takdirde toplanması ve tüm deliller birlikte değerlendirilerek hasıl olacak sonuca göre karar vermek ibarettir. Durum böyleyken; mahkemece açıklanan yönde işlem yapılmadan, eksik incelemeyle davanın reddine karar verilmesi usul ve yasaya aykırı olmuş; bozmayı gerektirmiştir, (Erişim: 04.03.2021, www.legalbank.net)

140 Aynı yönde bkz. mülga TMK 205/II. 
itibaren baba olduğu iddia edilen kişiye karşı açılabilir ve mahkemenin verdiği kararla, baba ile çocuk arasında doğumdan itibaren geçerli bir soybağı kurulabilirr ${ }^{141}$. Çocuğun başka bir erkeğe soybağı ile bağlı olması halinde, bu erkeğin sadece soybağının reddi davası açma hakkı vardır; babalık davası açmaya hakkı yoktur ${ }^{142}$. TMK md. $303^{143}$ uyarınca, babalık davası, çocuğun doğumundan önce veya sonra açılabilir; hak düşürücü süreye tabi olan davada ananın dava açma hakkı doğumdan itibaren bir yıl geçmekle düşecektir ${ }^{144}$. Çocuk ile başka bir erkek arasında soybağ 1 ilişkisi varsa, bir yllık süre bu ilişkinin ortadan kalktığı tarihte işlemeye başlayacaktır. Şayet dava açılmamışsa ve bir yıllık hak düşürücü süre geçtikten sonra bu gecikmeyi haklı kılan sebepler varsa, sebebin ortadan kalkmasından başlayarak bir ay içinde dava açılabilecektir (TMK md. 303). Ayrıca, görülmekte olan bir soybağının reddi davası varsa, babalık davası görülürken bu dava bekletici mesele yapılacaktır ${ }^{145}$. $\mathrm{Bu}$ halde, ananın davacı olduğu bu dava, yukarıda bahsettiğimiz soybağının reddi davasına dair kararın kesinleşmesinden sonra açllabilecektir.

\section{b. Yetkili Mahkemenin Tesisi}

Yabancıların kişi hallerine ilişkin bazı davalar başlıklı MÖHUK md. 42'de numerus clausus usulü benimsenmiştir ve madde kapsamında yabancıların kişi hallerine dair sınırlı sayıdaki davalarına yer verilmiştir. Bu madde uyarınca, Türkiyedde yerleşim yeri bulunmayan yabancı hakkında vesayet, kayyımlık, kısttlılık, gaiplik ve ölmüşs sayılma kararları ilgilinin Türkiye’de sakin olduğu yer, sakin değilse mallarının bulunduğu yer mahkemesince verilecektir. MÖHUK md. 42'nin içeriğine baktığımızda, çekişmesiz yargı işlerinin de madde kapsamına dahil edildiğini görmekteyiz ${ }^{146}$.

141 Öztan, s. 933; Demirbaş, s. 28 vd.

142 Kutoğlu, s. 960. Bunun diğer bir gerekçesi Birleşmiş Milletler Çocuk Hakları Sözleşmesi md. 7/I hükmüdür. Sözleşme md. 7/I uyarınca, çocuk doğumdan hemen sonra derhal nüfus kütüğüne kaydedilecek ve doğumdan itibaren bir isim hakkına, bir vatandaşlık kazanma hakkına ve mümkün olduğu ölçüde ana-babasını bilme ve onlar tarafından bakılma hakkına sahip olacaktır. Sözleşme, 27.01.1995 tarihinden itibaren Türkiye'de yürürlüğe girmiştir. RG. 27.01.1995/22184.

143 TMK md. 303'ün ikinci fikrası Anayasa Mahkemesi’nin 27.10.2011 tarihli, E.: 2010/71, K.: 2011/143 sayll kararı ile iptal edilmiştir; o nedenle bu husustaki tartışmalara yer verilmeyecektir.

144 Yargıtay 8. HD. E. 2017/12018, K. 18.05.2017, “Dava dilekçesinde, davacı ...’in gerçek babasının uzun yllar annesi ... ile evlilik dışı birlikte yaşadığı ... olduğunu, annesinin daha sonra kayden babası olan ... ile evlenmesi ile onun çocuğu olarak nüfusa tescil edildiğini beyan ederek babasının ... olduğunun tespitine karar verilmesini istenmiş, mahkemece ilk önce babalık davası için öngörülen hak düşürücü sürenin geçtiği gerekçesiyle dava reddedilmiş, temyiz üzerine karar (Kapatılan) 18. Hukuk Dairesince, babalığın tespiti davalarında çocuk yönünden hak düşürücü sürenin AYM tarafından iptal edildiği, baba olduğu iddia olunan ...’nin mirasçllarının davaya dahil edilerek taraf teşkilinin sağlanması, iddia hakkında DNA testi yaptırılması ile oluşacak sonuca göre karar verilmesi yönünde bozulmuștur. Bozma ilamına uyularak yapılan yargılama sonucu ...'in davacının babası olduğunun tespitine ve nüfusa kayıt ve tesciline karar verilmesi üzerine; hüküm, yasal mirasçı Hazine vekili tarafından temyiz edilmiştir. Bilindiği üzere usul kuralları (görev konusu, hak düşürücü süre, kesin hüküm itirazı, harç ve maddi hata) kamu düzeni ile doğrudan bağlantılı olup, taraflar yararına usulü kazanılmış hak oluşturmamaktadır (Yargitay Hukuk Genel Kurulu’nun 15.03.1972 gün ve 1968/1-277-176, 01.03.1995 gün ve 1995/7-641-117, 23.01.2002 gün ve 2001/1-1010-2002/1, 12.07.2006 gün ve 2006/4-519-527 say1l kararları, Baki Kuru, Hukuk Muhakemeleri Usulü-2001 Baskı, cilt 5, sayfa 4771 vd.).04.06.1958 ve 15/6 sayılı Yargitay İçtihadı Birleștirme kararı gereğince, maddi olayları açıllamak taraflara ve ileri sürülen olayları hukuken nitelemek ve uygulanacak Kanun hükümlerini tespit etmek ve uygulamak görevi hakime aittir..., (Erişim: 04.03.2021, www.legalbank. net)

145 Kutoğlu, s. 964.

146 Özkan/Tütüncübaşı, s. 84. 
Babalığın tespitine yarayan dava, MÖHUK md. 42'de sayılan davalar arasında yer almamaktadır. Babalık davasının amacı, yukarıdaki örneğimiz uyarınca Türk vatandaşı baba tarafından soybağı reddedilen çocuğun, yabancı devlet vatandaşı erkekle arasında soybağını kurmaktır. Çocuğun Türk vatandaşı olduğunu varsaydığımızda, kişisel hale ilişkin babalık davasında yetkili mahkemenin MÖHUK md. 41 uyarınca belirlenmesi gerektiği düşünülebilir. MÖHUK md. 41 uyarınca, Türk vatandaşlarının kişi hallerine ilişkin davaları, yabancı ülke mahkemelerinde açılmadığı veya açılamadığı takdirde Türkiyede yer itibariyle yetkili mahkemede (TMK md. 283, HMK md. 6, HMK md. 9), bulunmaması halinde ilgilinin sakin olduğu yer, Türkiye'de sakin değilse Türkiye'deki son yerleşim yeri mahkemesinde, o da bulunmadığı takdirde Ankara, İstanbul veya İzmir mahkemelerinden birinde görülecektir. Yukarıda izah edildiği üzere, bu davanın taraflarından bir tanesinin Türk vatandaşı olması yeterlidir. Yabancı kadının açtığı davada, yabancı devlet vatandaşı biyolojik babaya soybağı ile bağlanmak istenen çocuk şayet Türk vatandaşı değilse, bu halde MÖHUK md. 40'tan hareketle iç hukuka gidilecektir. Bu davalarda kesin yetki söz konusu değildir; o nedenle HMK ve TMK hükümlerine bakılması gerekir. TMK md. 283 uyarınca dava, taraflardan birinin dava veya doğum sırasındaki yerleşim yeri mahkemesinde açılabilir. O halde, yetki tesisi için, çocuğun veya ana babadan hangisiyle arasında ihtilaf varsa o kişinin dava veya çocuğun doğumu anındaki yerleşim yeri mahkemesini tespit etmek gerekecektir ${ }^{147}$. 4787 sayılı Aile Mahkemelerinin Kuruluş邓, Görev ve Yargılama Usullerine Dair Kanun md. 4 uyarınca, babalık davalarında aile mahkemeleri görevlidir. HMK md. 6'da yer alan genel yetki kuralı uyarınca, davalının davanın açıldığı tarihteki yerleşim yeri mahkemesi genel yetkiyi düzenlemektedir; davalının Türkiye'de yerleşim yeri bulunmaması halinde ise HMK md. 9 uyarınca Türkiye'deki mutad mesken yeri mahkemesinde dava açılabilir ${ }^{148}$.

\section{c. Babalık Davasında Uygulanacak Hukuk}

Yabancılık unsuru taşıyan babalık davasının açılma şartları, davanın kime karşı açılacağı, dava açma süresi ile sürenin niteliği ve babalık karinesinin şartları MÖHUK md. 16/I’de düzenlenen hukuklara göretespitedilecektir ${ }^{149}$. MÖHUKmd. 16/I’egöre, soybağının kuruluşu, çocuğun doğum anındakimilli hukukuna, kurulamaması hâlinde çocuğun mutad meskeni hukukuna tabidir. Soybağı bu hukuklara göre kurulamıyorsa, ananın veya babanın, çocuğun doğumu anındaki milli hukuklarına, bunlara göre kurulamaması halinde ana ve babanın, çocuğun doğumu anındaki müşterek mutad mesken hukukuna, buna göre de kurulamıyorsa çocuğun doğum yeri hukukuna tabi olarak kurulacaktır ${ }^{150}$.

147 Tan Dehmen, s. 189.

148 Aynı yönde bkz. Tan Dehmen, s. 189.

149 Çelikel/Erdem, s. 274; Can/Toker, s. 218.

150 İzmir BAM 2. HD. , E. 2017/519, K. 22.03.2017, “Dava dilekçesindeki iddialardan, davacı küçüğün Rusya’da Türk vatandaşı olan davalıların murisi ........'in evlilik dışı ilişkisinden Rusya vatandaşı .......'dan dünyaya geldiği, Vatandaşlık Kanunun 7/3 maddesine göre, küçüğün soybağı kurulmasını sağlayan usul ve esasların yerine getirilmesi halinde Türk Vatandaşlı̆̆ını kazanacağı, 5718 sayılı Milletlerarası Özel Hukuk ve Usul Hukuku Hakkında Kanunun 16/1. maddesi de "soybağının kuruluşu, çocuğun doğum anındaki milli hukukuna, kurulamaması halinde çocuğun mutad meskeni hukukuna tabidir. Soybağı bu hukuklara göre kurulamıyorsa, ananın veya babanın, çocuğun doğumu anındaki milli hukuklarına, bunlara göre kurulamaması halinde ana ve babanın, çocuğun doğumu anındaki müşterek mutad mesken hukukuna, buna göre de kurulamıyorsa çocuğun doğum yeri hukukuna tabi olarak kurulur.", aynı yasanın $2 / 1$. maddesi ise "Hakim, Türk kanunlar ihtilafı kurallarını ve bu kurallara göre yetkili olan yabancı hukuku re’sen uygular. 
Yukarıda MÖHUK md. 16/I'de basamaklı bir sistemin benimsendiği; bir basamak tüketilmeden bir sonraki basamağa geçilemeyeceği ifade edilmişti. Ancak ilk basamak uyarınca soybağının kurulması mümkün değilse bir sonraki basamağa geçilmektedir. MÖHUK md. 16/I uyarınca ihtilafa yabancı hukuk uygulandığında ortaya çıkan netice Türk kamu düzenine açık aykırılık teşkil ediyorsa, acaba bu tartışmada MÖHUK md. 5 uyarınca Türk hukukuna mı gidilmelidir yoksa MÖHUK md. 16/I'de yer alan bir sonraki basamağa mı geçilmelidir? Bu aşamda, iki görüş sunabiliyoruz. İlk görüş uyarınca, MÖHUK md. 5'e öncelikli olarak etki tanınabilir. Şöyle ki, kanun koyucu MÖHUK md. 16/I'de soybağının "kurulamaması" halinde bir sonraki basamağa geçileceğini ifade etmektedir. MÖHUK md. 5 'in fonksiyonu, yabancı hukukun belirli bir olaya uygulanan hükmünün Türk kamu düzenine açıkça aykırı olması halinde, bu hükmün uygulanmayacağı; gerekli görülen hallerde Türk hukukunun uygulanacağıdır. Dolayısıyla, MÖHUK md. 16/I uyarınca tespit edilen hukuk, Türk kamu düzenine açık aykırılık teşkil ediyorsa bu halde, bir sonraki basamağa geçilmeden MÖHUK md. 5 uyarınca ihtilafa Türk hukuku uygulanabilir. İkinci görüş, MÖHUK md. 5’in istisnai olarak uygulanması gerektiğine hizmet etmektedir, zira MÖHUK md. 5 uyarınca, yetkili yabancı hukukun belirli bir olaya uygulanan hükmünün Türk kamu düzenine açıkça aykırı olması halinde, bu hüküm uygulanmaz; gerekli görülen hallerde, Türk hukuku uygulanacaktır. MÖHUK md. 5'in istisnai olarak uygulanması gerektiği doktrinde ifade edilmektedir ${ }^{151}$. Bu nedenle, ilk basamakta yabancı hukukun ihtilafa uygulanması neticesinde ortaya çıkan sonuç Türk kamu düzenine açıkça aykırı olsa da, MÖHUK md. 5 istisnai olarak uygulanacağından, doğrudan Türk hukukuna gidilemeyecek, bir sonraki basamağa geçilebilecektir. Tartışma kapsamında sunduğumuz iki görüşten ikincisine katıldığımızı belirtmek isteriz. Bu görüş, MÖHUK md. 5 'in istisnai olarak uygulanması prensibine daha uygundur. Ayrıca soybağı ile ilgili neticenin soybağına dair düzenlenmiş kanunlar ihtilafı kuralının sunduğu tüm basamaklar tüketilerek uygulanacak hukuka erişilmesinin maddenin konuluş amacına daha uygun olduğunu düşünmekteyiz.

\section{SONUÇ}

Çocuğun soybağının tespiti nesiller boyu hukuk camiasını ilgilendirmiş bir meseledir. Evliliğin boşanmayla sona ermesi ve kadının yeniden evlenmesi halinde kadının hamile olup olmadığının bilinmemesi, kadına yönelik bir evlenme engelinin ortaya çıkmasına neden olmuştur. Çalışmamızda İslam hukukunun yanında mukayeseli hukuka yer vermemizin nedeni, iddet müddeti ile ilgili düzenlemelerin sadece İslam hukukunun tesiri altında kalan ülkelerde değil, birçok farklı hukuk

Hakim, yetkili yabancı hukukun muhtevasının tespitinde tarafların yardımını isteyebilir." hükümlerini içermektedir. Davada yabancıllk unsuru bulunmasına göre, mahkemece uygulanması gereken yabancı hukukun; 5718 sayılı Yasanın 2. maddesi ile Türkiye’nin de taraf olduğu Yabancı Hukuk Hakkında Bilgi Edinilmesine Dair Avrupa Sözleşmesinin 1-5. maddeleri uyarınca belirlenmesinden sonra tarafların göstereceği tüm deliller toplanıp, sonucuna göre bir karar verilmesi gerekirken yazılı şekilde davanın kabulü yönünde hüküm kurulmuş olması doğru görülmemiştir. Babalığın tespitine ilişkin açılan davalar, soybağının doğru olarak tespit edilmesi gerekmekle, kamu düzenine ilişkin davalardır. Anılan eksiklik bu nedenle HMK.355 maddesi uyarınca, istinaf incelemesi sırasında resen gözetilmesi gerektiğinden, bu konuda istinaf başvurusu olmaması sonuca etkili değildir” (Erişim: 04.03.2021, www.legalbank.net)

151 Nomer, s. 162; Şanlı/Esen/Ataman Figanmeşe, s. 87; Çelikel/Erdem, s. 151; Güngör, s. 103; Doğan, s. 257; Tekinalp, s. 45; Can/Toker, s. 144. 
sisteminde de yer aldığını göstermektedir. Ancak 1945’li yıllarda Kıta Avrupası hukuk sisteminde yapılan kanunlaşma çalışmalarında iddet müddetinin yasalardan çıkartıldığını; yabancı doktrinde ise bu konunun artık tartışılmadığını görmekteyiz. Türk hukuk sisteminde iddet müddetine dair düzenlememiz daima muhafaza edilmiştir. Türk vatandaşı kadının yeniden evlenmesi halinde iddet müddetine uyması veyahut bu sürenin kaldırılması için dava açması gerekmektedir. Ülkemizde iddet müddetinin kaldırılması davası sürecinde kadının bileğinin mühürlenmesi uygulamasının yazılı olduğu yasal düzenlemeyi araştırmalarımıza rağmen tespit edemedik; fakat mahkemeden hastaneye sevk sürecinin bir insanın bileğinin mühürlenerek yapılmasının çağımıza uymayan bir yapıya sahip olduğunu ve AİHS md. 8'e aykırılık oluşturduğunu düşünmekteyiz.

Yabancı devlet vatandaşı kadının Türk vatandaşı erkekle yapacağı evlilikte, evlenme ehliyet ve şartları kadının kendi milli hukukuna tabi olacaktır. Bu hukuk iddet müddeti ile ilgili bir düzenleme içermiyorsa, yabancı devlet vatandaşı kadından bu şartın yerine getirilmesi beklenemez. Yabancı devlet vatandaşı kadın, Türk erkekle olan evliliğinden önce yabancı devlet vatandaşı bir erkekten hamile kalmışsa, Türk vatandaşı erkek bu durumu bilmeyerek dünyaya gelen çocuğun kendi çocuğu olduğunu düşünebilir. Bu halde, evlilik içerisinde doğacak olan çocuğun babasının Türk vatandaşı erkek olduğu kabul edilecektir. Bu hususu bilmeden evlenen Türk vatandaşı erkek, babalık karinesinin çürütülmesi amacıyla soybağının reddi davasını açabilir. Bu davada yetkili mahkemenin tesisi MÖHUK md. 41 uyarınca belirlenecektir. Davada uygulanacak hukuk ise MÖHUK md. 16/ II uyarınca soybağının reddine uygulanacak hukuk kapsamında tespit edilecektir. Diğer yandan, yabancı devlet vatandaşı kadın, Türk vatandaşı erkekle soybağı kesilmiş çocuğa dair babalık davası açarak çocuğu yabancı devlet vatandaşı biyolojik babanın soybağına bağlamak isteyebilir. Bu davada yetkili Türk mahkemesi çocuğun vatandaşlığına göre değişecektir; uygulanacak hukuk ise MÖHUK md. 16/I uyarınca tespit edilecektir.

Önemle belirtmek isteriz ki, çalışmamızın amacı iddet müddetinin düzenlenmediği hukuklarda soybağı tespitinde hiçbir sorun olmadığına işaret etmek değildir. Aynı şekilde, iddet müddetinin düzenlendiği devlet hukuklarında bazı problemler yaşanabilir. Zira ailenin esas alındığı bir meselede her toplumun farklı dinamikleri bulunmaktadır. Hukukun kuvveti ise, müstakbel ihtilaflara dair muhtelif çözümler yaratabilmesinden gelmektedir. Çalışmada, iddet müddetinden kaynaklanan bir ihtilaf üzerinde durularak, soybağının reddi ve babalık davalarında uygulanacak hukuk ve yetkili mahkeme tespit edilmeye çalışılmıştır. İncelememizde yer alan MÖHUK’un ilgili maddelerinin vatandaşlık bağlama noktasına önem vermesi nedeniyle, MÖHUK md. 4 üzerinde ayrıca durulmaya çalışılmıştır.

\section{KAYNAKLAR}

Akıncı, Ziya, Milletlerarası Usul Hukukunda Yetki Sözleşmesine Dayanan Milletlerarası Derdestlik, Ankara, 2002.

Akıncı, Ziya/Gökyayla Demir, Cemile, Milletlerarası Aile Hukuku, İstanbul 2010.

Akıntürk, Turgut, Türk Medeni Hukuku, Cilt: 2, Aile Hukuku, İstanbul 2006.

Akıntürk, Turgut/Ateş Karaman, Derya, Türk Medeni Hukuku Aile Hukuku, İstanbul 2013. 
Altıner Yolcu, Fatma Zeynep, Soybağının Reddi Davasında Biyolojik Baba, İstanbul Aydın Üniversitesi Hukuk Fakültesi Dergisi, 6/2-2020.

Ansay, Sabri Şakir, Hukuk tarihinde İslam Hukuku, Ankara 1958.

Ataman Figanmeşe, İnci, Çifte Vatandaşlık Halinde MÖHUK’un 4. maddesinin b ve c Bendlerinin Uygulama Alanı, MHB, Aysel Çelikel’e Armağan, Sayı: 1-2, 1999/2000.

Aybay, Rona/Dardağan, Esra, Uluslararası Düzeyde Yasaların Çatışması, İstanbul 2008.

Aydın, Mehmet Akif, Türk Hukuk Tarihi, İstanbul 2010.

Basedow, Jürgen, Das Staatsangehörigkeitsprinzip in der Europäischen Union, IPRax 2011.

Beitzke, Günther, Familienrecht: ein Studienbuch, München 1985.

Berki, Şakir, Evlenmenin Asli Şartlarından Doğan Kanun İhtilafları ve Türk Hukukundaki Tatbikatı, Ankara Üniversitesi Hukuk Fakültesi Dergisi, Cilt: 8, Sayı: 1-2, 1951.

Can, Hacı/Toker, Ali Gümrah, Milletlerarası Özel Hukuk, Ankara 2016.

Cin, Halil, İslam ve Osmanlı Hukukunda Evlenme, Ankara 1974.

Çelikel, Aysel/Bahadır, Erdem, Milletlerarası Özel Hukuk, İstanbul 2020.

Dağcı, Şamil, İslam Aile Hukukunda Evlenme Engelleri I (Sürekli Evlenme Engelleri), Ankara Üniversitesi İlahiyat Fakültesi Dergisi, 39-I/1999.

Dağcl, Şamil, İslam Aile Hukukunda Evlenme Engelleri II (Geçici Evlenme Engelleri), Ankara Üniversitesi İlahiyat Fakültesi Dergisi, 2000, Cilt: XLI, 2000 (kısaltma: Geçici Evlenme Engelleri).

Demirbaş, Feride, Baba İle Çocuk Arasındaki Soybağına İlişkin Davalarda Davacı Olabilecek Kişiler, Ankara Hacı Bayram Veli Üniversitesi Hukuk Fakültesi Dergisi, Cilt: XXII, Sayı: 3, 2018.

Doğan, Vahit, Milletlerarası Özel Hukuk, Ankara 2020.

Dural, Mustafa/Öğüz, Tufan/Gümüş, Alper, Türk Özel Hukuku, Cilt: 3, Aile Hukuku, İstanbul 2005.

Erdem, Suat, İslam Hukukuna Göre İddet ve İddet Bekleyen Kadının Nikahı, Cumhuriyet Üniversitesi İlahiyat Fakültesi Dergisi, Cilt: XVII, Sayı: 2, 2013.

Erten, Rifat, Türklerin Kişi Hallerine İlişkin Davalarda Türk Mahkemelerinin Milletlerarası Yetkisi, Ankara 2017.

Feyzioğlu, Feyzi Necmettin, Aile Hukuku, İstanbul 1996.

Fuchs, Angelika, Neues Staatsangehörigkeitsgesetz und Internationales Privatrecht, NJW 2000.

Gayretli Aydın, Seda, Kadın ve Kanuni Bekle Süresi, TBB Dergisi 136/2018.

Gençcan, Ömer Uğur, Aile Hukuku, İstanbul 2011.

Giray, Faruk Kerem, 4721 sayılı Türk Medeni Kanununda Yer Alan Aile Konutu Kavramının Kanunlar İhtilafı Hukuku Bakımından Değerlendirilmesi, MHB, 23/1-2, 2003.

Görgülü, Ülfet, İslam Aile Hukukunda Bid'î Talak Meselesi, İslam Hukuku Araştırmaları Dergisi, 30/2017.

Güngör, Gülin, Türk Milletlerarası Özel Hukuku, Ankara 2021.

Gümüş, Alper M., Koca, Çocuk ve Ergin Olmayan Çocuğa Atanan Kayyım Dışındaki Diğer İlgililerin (Kocanın Ana ve Babası ile Altsoyunun, Baba Olduğunu İddia Eden Kişinin, Annenin (!)) Soybağının Reddi Davası Açma Hakkı (TMK md. 291/I), Prof. Dr. Mustafa Dural’a Armağan, İstanbul 2013.

Hailbronner, Kay, Staatsangehörigkeit und IPR, in: Hailbronner, Kay/Maaßen, Hans-Georg/Hecker, Jan/Kau, Marcel, Staatsangehörigkeitsrecht, München 2017.

Helvacı, İlhan, Gerekçeli Karşılaştırmalı İçtihatlı Türk Medeni Kanunu Cilt II, Aile Hukuku, İstanbul 2013.

Helvac1, Serap/Erlüle, Fulya, Medeni Hukuk, İstanbul 2016.

Kutoğlu, Tuba, Türk Mevzuatında ve İçtihatlarında Babalık Hükmü, Dokuz Eylül Üniversitesi Hukuk Fakültesi Dergisi Cilt: 12, 2010. 
Lorenz, Stephan, EGBGB Art. 5, in: Hau, Wolfgang/Poseck, Roman, BeckOK BGB, 2021.

Mansel, Heinz-Peter, Personalstatut, Staatsangehörigkeit und Effektivität, München 1988.

Martiny, Dieter, Probleme der Doppelstaatsangehörigkeit im deutschen Internationalen Privatrecht, JZ, 23/1993.

Nomer, Ergin, Türk Devletler Özel Hukukunda Çifte Vatandaşlık, MHB, 14/I-II, 1994 (kısaltma: Çifte Vatandaşlik).

Nomer, Ergin, Devletler Hususi Hukuku, İstanbul 2017.

Oğuzman, Kemal/Dural, Mustafa, Aile Hukuku, İstanbul 2001.

Özel, Sibel, Yabancılık Unsuru Taşıyan Bireysel İş Sözleşmelerinden Kaynaklanan Uyuşmazlıklarda Türk Mahkemelerinin Yetkisi: MÖHUK m. 44, Bahçeşehir Üniversitesi Hukuk Fakültesi Dergisi, 179/2019.

Özgenç, Zeynep, Velâyete Uygulanacak Hukukun Tespitinde Kamu Düzeni Müdahalesine İlişkin Değerlendirmeler, Ankara Hacı Bayram Veli Üniversitesi Hukuk Fakültesi Dergisi, Sayı: 1, XXII/ 2018.

Özkan, Işı1/Tütüncübaşı, Uğur, Uluslararası Usul Hukuku, Ankara 2017.

Öztan, Bilge, Aile Hukuku, Ankara 2015.

Öztan, Bilge, s. Batıl Evlenmelerde Eşlerin Durumu, Ankara Üniversitesi Hukuk Fakültesi Dergisi 26/1-2, 1969 (Kisaltma: Batıl Evlenme).

Öztekin Gelgel, Günseli, Devletler Özel Hukukunda Velayet, Çocuk Kaçırmaları, Evlat Edinmeye İlişkin Problemler, İstanbul Ticaret Üniversitesi Sosyal Bilimler Dergisi, Yll: 4/8, 2005/2.

Paksoy, Gülnihal, Soybağının Reddi, TBB Dergisi 97/2011.

Paksoy Erbaydar, Nüket/Balseven Odabaşı, Aysun, Medeni Kanunun Bekleme Süresi (İddet Müddeti) İle İlgili 132. Maddesinin Kadın Hakları ve Modern Tiptaki Gelişmeler Işı̆̆ında Değerlendirilmesi, Fe Dergi, $10 / 2018$.

Pürselim, Hatice Selin, Mültecilerin Hukuki Statüsüne İlişkin Cenevre Sözleşmesỉne Yönelik İki Tartışma: Sözleşme’nin Kapsadığı Kişiler ve Geri Göndermeme İlkesinin Bağlayıcılığı, Prof. Dr. Necla Giritlioğlu’na Armağan, (Ed. Erman, Hasan/ Öğüz, Tufan/ Şıpka, Şükran/İnal, Emrehan/ Baysal, Başak), İstanbul 2020.

Pürselim Arning, Temel Kavramlar Işığında Mülteci Hukukunun Gelişimi, (Ed. Öner, Aslı Şirin/Ihlamur Öner, Suna Gülfer) Uluslararası İlişkilerde Göç, İstanbul 2018.

Pürselim Arning, Türk, Alman ve İsviçre Milletlerarası Özel Hukuklarında Ad, - Ada, Ad Değiştirme Davasına, Kayıt Düzeltme Davasına Uygulanacak Hukuk ve Tanıma Usulü-, Ankara 2014.

Rauscher, Thomas, Familienrecht, München/Heidelberg 2008.

Rentsch, Betina, Die Zukunft des Personalstatuts im gewöhnlichen Aufenthalt, ZeuP, 2015.

Saar, Stefan Chr., Ehe, Scheidung, Wiederheirat: zur Geschichte des Ehe - und des Ehescheidungsrecht im Frühmittelalter (6.-10. Jahrhundert), (Ed.; Holzhauer, Heinz/Roth, Andreas, Ius Vivens Band: 6, Münster 2002.

Sayman, Yücel, Türk Devletler Hususi Hukukunda Evlenmenin Kuruluşu, İstanbul Üniversitesi Hukuk Fakültesi Yayınları, İstanbul 1982.

Schulze, Reiner, Art. 5 EGBGB, in: Nomos Kommentar BGB I, Baden Baden 2012.

Stehlin, Philipp, Das Personen - und Familienrecht des ZBG von 1912: Eine inhaltliche Untersuchung der Gesetzeskommentare des August Egger (1875-1954), Bern 2018.

Şanlı, Cemal/Esen, Emre/Ataman Figanmeşe, İnci, Milletlerarası Özel Hukuk, İstanbul 2021.

Tan Dehmen, Mine, Türk Vatandaşlarının Kişi Hallerine İlişkin Davalar Bakımından 5718 Sayılı MÖHUK’ta Kabul Edilen Yetki Kuralı, MHB, Cilt:33, Sayı: 1, 2013. 
Tanrıbilir, Feriha Bilge, Yabancıların Türk Yetkili Makamları Önünde Evlenmesi ve Kamu Düzenine Aykırılık Meselesi, Milletlerarası Özel Hukukta Güncel Konular Sempozyumu, (Ed. Tiryakioğlu, Bilgin/Aygün, Mesut/ Altıparmak, Kübra, Ankara 2016.

Tanrıbilir, Feriha Bilge, Çocuk Haklarının Uluslararası Korunması ve Koruma Mekanizmaları, Ankara 2011 (kısaltma: Koruma Mekanizmaları).

Tekinalp, Gülören, Milletlerarası Özel Hukuk Bağlama ve Usul Hukuku Kuralları, İstanbul 2020.

Tiryakioğlu, Bilgin, Türklerin Kişi Hallerine İlişkin Davalarda Türk Mahkemelerinin Milletlerarası Yetkisi, Tuğrul Arat’a Armağan, Ankara 2012.

Uludağ, Sabiha Nur, Evlenmenin Hükümsüzlüğü Sebepleri, Çankaya Üniversitesi Sosyal Bilimler Enstitüsü Özel Hukuk Anabilim Dalı, yayımlanmamıs yüksek lisans tezi, Aralık 2019.

Uyanık Çavuşoğlu, Yeni MÖHUK’a Göre Soybağı İlişkisine Uygulanacak Hukuk Sorunu, Maltepe Üniversitesi Hukuk Fakültesi Dergisi, 2008/2.

https://www2.tbmm.gov.tr (Erişim: 04.03.2021).

https://islamansiklopedisi.org.tr/iddet (Erişim: 04.03.2021).

www.legalbank.net (Erişim: 04.03.2021).

https://www.vfst.de/apps/elbib/A153 (Erişim: 04.03.2021).

http://www.koeblergerhard.de/Fontes/ZGB1907.htm (Erişim: 04.03.2021).

\section{KISALTMALAR}

$\begin{array}{ll}\text { AİHS } & \text { Avrupa İnsan Hakları Sözleşmesi } \\ \text { BAM } & \text { Bölge Adliye Mahkemesi } \\ \text { BGB } & \text { Bürgerliches Gesetzbuch } \\ \text { bkz. } & \text { bakınız } \\ \text { E. } & \text { Esas } \\ \text { Ed. } & \text { Editörler } \\ \text { EheschlRG } & \text { Gesetz zur Neuordnung des Eheschließungsrechts (Eheschließungsrechtsgesetz) } \\ \text { GÜHFD } & \text { v. 4.5.1998 (BGBl. I S. 833) } \\ \text { HD. } & \text { Galatasaray Üniversitesi Hukuk Fakültesi Dergisi } \\ \text { JZ } & \text { Hukuk Dairesi } \\ \text { K. } & \text { Juristen Zeitung } \\ \text { md. } & \text { Karar } \\ \text { MHB } & \text { madde } \\ \text { MÖHK } & \text { Milletlerarası Hukuk ve Milletlerarası Özel Hukuk Bülteni } \\ \text { MÖHUK } & \text { Milletlerarası Özel Hukuk Hakkında Kanun } \\ \text { RG. } & \text { Milletlerarası Özel Hukuk ve Usul Hukuku Hakkında Kanun } \\ \text { s. } & \text { Resmi Gazete } \\ \text { TBB } & \text { sayfa } \\ \text { TMK } & \text { Türkiye Barolar Birliği } \\ \text { vd. } & \text { Türk Medeni Kanunu } \\ \text { ZeuP } & \text { ve devamı } \\ & \text { Zeitschrift für Europäisches Privatrecht. }\end{array}$

